\title{
Adult Phenotypes in Angelman- and Rett-Like Syndromes
}

\author{
M.H. Willemsen ${ }^{a} \quad$ J.H.M. Rensen ${ }^{a, b} \quad$ H.M.J. van Schrojenstein-Lantman de Valk \\ B.C.J. Hamela T. Kleefstra ${ }^{a}$ \\ ${ }^{a}$ Department of Human Genetics, Radboud University Nijmegen Medical Centre, Nijmegen, \\ bPluryn, Support for People with Disabilities, Oosterbeek, and 'Department of Primary and Community Care, \\ Radboud University Nijmegen Medical Centre, Nijmegen, The Netherlands
}

\section{Key Words}

Adult phenotypes - Angelman- and Rett-like syndromes .

CDKL5 - Dravet syndrome - Kleefstra syndrome ·

Male MECP2 - Phelan-McDermid syndrome - Pitt Hopkins syndrome

\section{Abstract \\ Background: Angelman- and Rett-like syndromes share a range of clinical characteristics, including intellectual dis- ability (ID) with or without regression, epilepsy, infantile en- cephalopathy, postnatal microcephaly, features of autism spectrum disorder, and variable other neurological symp- toms. The phenotypic spectrum generally has been well studied in children; however, evolution of the phenotypic spectrum into adulthood has been documented less exten- sively. To obtain more insight into natural course and prog- nosis of these syndromes with respect to developmental, medical, and socio-behavioral outcomes, we studied the phenotypes of 9 adult patients who were recently diag- nosed with 6 different Angelman- and Rett-like syndromes. Methods: All these patients were ascertained during an on- going cohort study involving a systematic clinical genetic diagnostic evaluation of over 250 , mainly adult patients with}

ID of unknown etiology. Results: We describe the evolution of the phenotype in adults with EHMT1, TCF4, MECP2, CDKL5, and SCN1A mutations and 22qter deletions and also provide an overview of previously published adult cases with similar diagnoses. Conclusion: These data are highly valuable in adequate management and follow-up of patients with Angelman- and Rett-like syndromes and accurate counseling of their family members. Furthermore, they will contribute to recognition of these syndromes in previously undiagnosed adult patients.

Copyright $\odot 2012$ S. Karger AG, Basel

Clinical characteristics of known syndromes including associated health and behavior issues and recognizable facial features are generally well studied and described in patients at childhood. Often little is known about evolution of the phenotype across life span. Information on health and social outcomes is necessary for an adequate management and follow-up of patients with specific intellectual disability (ID) syndromes and enables careful counseling of family members regarding prognosis, natural course of the disease, and life expectancy. Delineation of phenotypes at adult age will also

\section{KARGER \\ Fax +4161306 1234 \\ E-Mail karger@karger.ch}

www.karger.com
(C) 2012 S. Karger AG, Basel

$1661-8769 / 11 / 0025-0217 \$ 38.00 / 0$

Accessible online at:

www.karger.com/msy
Marjolein Willemsen

849 Department of Human Genetics

PO Box 9101

NL-6500 HB Nijmegen (The Netherlands)

Tel. +31 24361 3946, E-Mail m.willemsen@antrg.umcn.nl 
contribute to recognition and diagnosis of ID syndromes in adults.

In the past decade improvements in diagnostic and research technologies have led to the identification of several novel chromosomal microdeletions and -duplications as well as single genes that are associated with known and novel ID syndromes, referred to as 'Angelman- and Rett-like syndromes' [Amir et al., 1999; Claes et al., 2001; Phelan et al., 2001; Kalscheuer et al., 2003; Wilson et al., 2003; Tao et al., 2004; Kleefstra et al., 2006; Zweier et al., 2007; Ariani et al., 2008; Papa et al., 2008; Zweier et al., 2010]. After the initial identification of the gene methyl CpG binding protein 2 (MECP2) as the cause of Rett syndrome [Amir et al., 1999], additional genes associated with a Rett-like/aspecific Rett syndrome phenotype have been subsequently identified. These include forkhead box G1 (FOXG1), cyclin-dependent kinase-like 5 (CDKL5), and myocyte enhancer factor 2C (MEF2C) [Kalscheuer et al., 2003; Tao et al., 2004; Ariani et al., 2008; Zweier et al., 2010]. Furthermore, in several patients with a clinical diagnosis of Angelman-like syndrome, mutations in MECP2 and CDKL5 have been identified [Watson et al., 2001; Moncla et al., 2002; Kleefstra et al., 2004; Russo et al., 2009]. In addition, several mutations in the gene transcription factor 4 (TCF4, Pitt Hopkins syndrome) have been identified in patients with Angelman-like phenotypes as well [Takano et al., 2010]. So, Angelman- and Rett-like syndromes have an overlapping phenotypic spectrum with heterogeneous underlying genetic defects which can mimic each other. The phenotypic spectrum comprises (severe) ID with or without regression, epilepsy, infantile encephalopathy, features of autism spectrum disorder, stereotypies and hand apraxia, postnatal microcephaly, autonomic dysfunction (including breathing anomalies, vasomotor disturbance, and gastro-intestinal symptoms), and other neurological symptoms, including ataxia and spasticity. Furthermore, various underlying genetic defects are thought to act in similar and/or interacting pathways. For example, $M E C P 2$ is thought to be involved in the epigenetic regulation of UBE3A (associated with Angelman syndrome) [Makedonski et al., 2005; Samaco et al., 2005]. Also, $M E C P 2, C D K L 5$, and $M E F 2 C$ were shown to interact directly which suggest involvement in a common pathway [Mari et al., 2005; Zweier et al., 2010].

During an ongoing cohort study among mainly adult patients with so far unexplained ID, we identified an associated genetic defect in 9 adult patients with Angelman- and Rett-like phenotypes. We found mutations in the genes TCF4, CDKL5, EHMT1 (euchromatic histone- lysine N-methyltransferase 1), MECP2, and SCN1A (sodium channel, voltage-gated, type I, alpha subunit), and small terminal deletions in chromosomal region 22q13.3, associated with Phelan-McDermid syndrome. Here we describe the evolution of their phenotypes up to different adult ages and give an overview of previously reported adult cases.

\section{Patients and Methods}

All patients were ascertained during an ongoing cohort study among patients with ID of unknown etiology. This study was approved by the local ethical committee. Patients were selected from a large population of approximately 4,000 people living in residential settings associated with 3 service providers for the care of people with ID in the eastern part of the Netherlands. Patients were selected on the base of an IQ level $\leq 70$ in combination with the presence of one or more of the following features: micro- or macrocephaly, growth retardation or overgrowth, neurological features (e.g. ataxia, spasticity, neurodegenerative signs), congenital anomalies (i.e. congenital heart/renal/skin/ genital defects), consanguinity and/or positive family history for ID, and/or dysmorphic features. More than $80 \%$ of the patients in the total cohort were adult patients. After obtaining written permission from the parents or legal representative for participation in this study, patients were invited to visit the department of human genetics at the Radboud University Nijmegen Medical Centre for an extensive multidisciplinary clinical evaluation. Specific DNA diagnostic tests were requested when indicated. In all patients, genome-wide SNP (single nucleotide polymorphism) array analysis was performed according to the standard Affymetrix GeneChip protocol (Affymetrix, Inc., Santa Clara, Calif., USA). In 8 patients the Affymetrix 250k array platform and in 1 patient (patient 7 ) the Affymetrix $2.7 \mathrm{M}$ array platform was used. Copy number estimates were determined using the updated version 2.0 of the CNAG (copy number analyzer for Affymetrix GeneChip mapping) software package (Affymetrix 250k SNP array) or the ChAS (chromosome analysis suite for Affymetrix GeneChip mapping) software package (Affymetrix $2.7 \mathrm{M}$ array). The normalized ratios were subsequently analyzed for genomic imbalances by a standard hidden Markov model. CNVs were mapped according to the UCSC genome browser build May 2004 (NCBI35/Hg17) for the Affymetrix 250k array platform and to build March 2006 (NCBI36/Hg18) for the Affymetrix $2.7 \mathrm{M}$ array platform.

All patients underwent screening metabolic tests in urine and serum as well, including quantification of lactate, amino acids, creatine biosynthesis, carnitines, organic acids, purines and pyrimidines, and transferrin subfractions.

\section{Segregation Analysis}

When possible, segregation of genetic/chromosomal variants was tested in the parents and/or other family members by SNP array, multiplex ligation-dependent probe amplification (MLPA), fluorescence in situ hybridization (FISH), or sequencing of the involved gene. 


\section{Results}

\section{Patient 1: Kleefstra Syndrome (EHMT1)}

This female patient was ascertained at the age of 41 years. She was born at term after an uncomplicated pregnancy and delivery in breech position. Birth weight was $>3 \mathrm{~kg}$ ( $>10$ th centile). At the age of 6 weeks she was admitted to the hospital because of persistent excessive regurgitation and weight loss, probably due to severe gastro-esophageal reflux. Her motor development was mildly delayed, with walking independently at the age of 18 months. Speech development was more severely delayed, and she was not able to speak single words until the age of 3 years. Contact making was diminished, and she had mood swings. An intravenous pyelogram at the age of 10 years because of recurrent urinary tract infections showed no abnormalities. Ophthalmological evaluation revealed substantial strabismus. At the age of 38 years her developmental age as assessed by the WISC-RN scale was 5.5 years with a discrepancy between verbal capacities (age equivalent 4.3 years) and performal capacities (age equivalent 6.6 years). She was able to walk, to talk in short simple sentences and needed some help in self care. Around the age of 38 years she presented with a remarkable change in her behavior pattern, including periods of apathy, decreased emotional responsiveness, staring, low motor activity, stupor, and sleep disturbance, characterized by frequent awakenings during the night and daytime sleepiness. Detailed behavioral characteristics have been published elsewhere [Verhoeven et al., 2011: patient 1]. Furthermore, impulsivity and aggressive outbursts were reported. She also showed focal myoclonic twitches of the right shoulder. Electro-encephalography was repeatedly normal. Brain MRI showed multifocal poorly defined abnormal white matter signal intensities, mainly localized deeply in the parietal lobe. In addition, bilaterally abnormal signal intensity in the globus pallidus was noticed. These abnormalities were not indicative for perinatal asphyxia. Cardiologic evaluation revealed hypertrophy of the left ventricle and paroxysmal atrial fibrillation. Upon physical examination at the age of 41 years, her height was $176 \mathrm{~cm}$ (75th centile), weight $103 \mathrm{~kg}$ (>98th centile), and head circumference $53.5 \mathrm{~cm}$ (10th centile). Facial dysmorphic features comprised a flat midface, slight upslant of the palpebral fissures, short philtrum, prognathism, and a full everted lower lip (fig. 1A, B). Chromosomal analysis by $250 \mathrm{k}$ SNP array analysis was normal, and screening metabolic tests revealed no abnormalities. Because of the clinical suspicion of Kleefstra syndrome without a deletion in chromosomal region 9q34.3, muta-

Adult Phenotypes in Angelman- and

Rett-Like Syndromes tion analysis of EHMT1 was performed and revealed a pathogenic mutation in the splice site of intron 20 of the EHMT1 gene (c.3087+1G>T). Segregation analysis in the parents was not possible.

\section{Patient 2: Pitt Hopkins Syndrome (TCF4)}

This male patient was ascertained at the age of 40 years. He was born at term after an uneventful pregnancy and delivery. Birth weight was $3,200 \mathrm{~g}$ ( $>20$ th centile). His psychomotor development was severely delayed. He was able to sit independently at the age of 4 years and able to walk at 8 years of age. He did not develop speech. His behavior was characterized by severe pica behavior, including the drift to ingest soft objectives such as socks. Several times he underwent a gastroscopy to remove socks from his stomach. To prevent further ingestion incidents, he was prescribed to wear a helmet with a face mask. In addition, he showed hyperactive and self-mutilation behaviors and had a high threshold of pain. During puberty he frequently had outbursts of crying, but later on he was generally in a happy mood. Apart from an atopic constitution presenting with allergy, asthma, and ecze$\mathrm{ma}$, his general health was quite good. After a fall at the age of 36 years, in addition to a fresh compression fracture of the twelfth thoracic vertebra, multiple old fractures, including metacarpal, humeral, and femoral fractures, were detected and he was diagnosed with osteoporosis. Ophthalmological evaluation revealed myopia. Upon physical examination at the age of 40 years his height was $173 \mathrm{~cm}$ (>2nd centile), weight $56 \mathrm{~kg}$ (16th centile), and head circumference $53.5 \mathrm{~cm}$ (0.6th centile). He showed evident facial dysmorphism including remarkable prognathism, a broad nose with full tip, hyperplastic alae nasi, broad mouth with downturned corners, and widely spaced teeth (fig. 1C, D). The chest was asymmetric with a mild pectus excavatum, and he had a mild left convex scoliosis. His feet were flat, and both hands showed short fifth fingers and tapering of the fingers with concave nails (fig. 2A, B). On the right hand a single palmar crease was present. He preferred to sit on the ground with his legs sideward rotated to the left. He had difficulties to stand up from this position and showed a mildly increased muscular tone. Chromosomal analysis by $250 \mathrm{k}$ SNP array analysis was normal, and screening metabolic tests revealed no abnormalities. Because of some facial characteristics of Pitt Hopkins syndrome, mutation analysis of TCF4 was requested and revealed a known pathogenic mutation (c.1739G >A, p.Arg580Gln). Segregation analysis in the parents showed that the mutation had occurred de novo. 


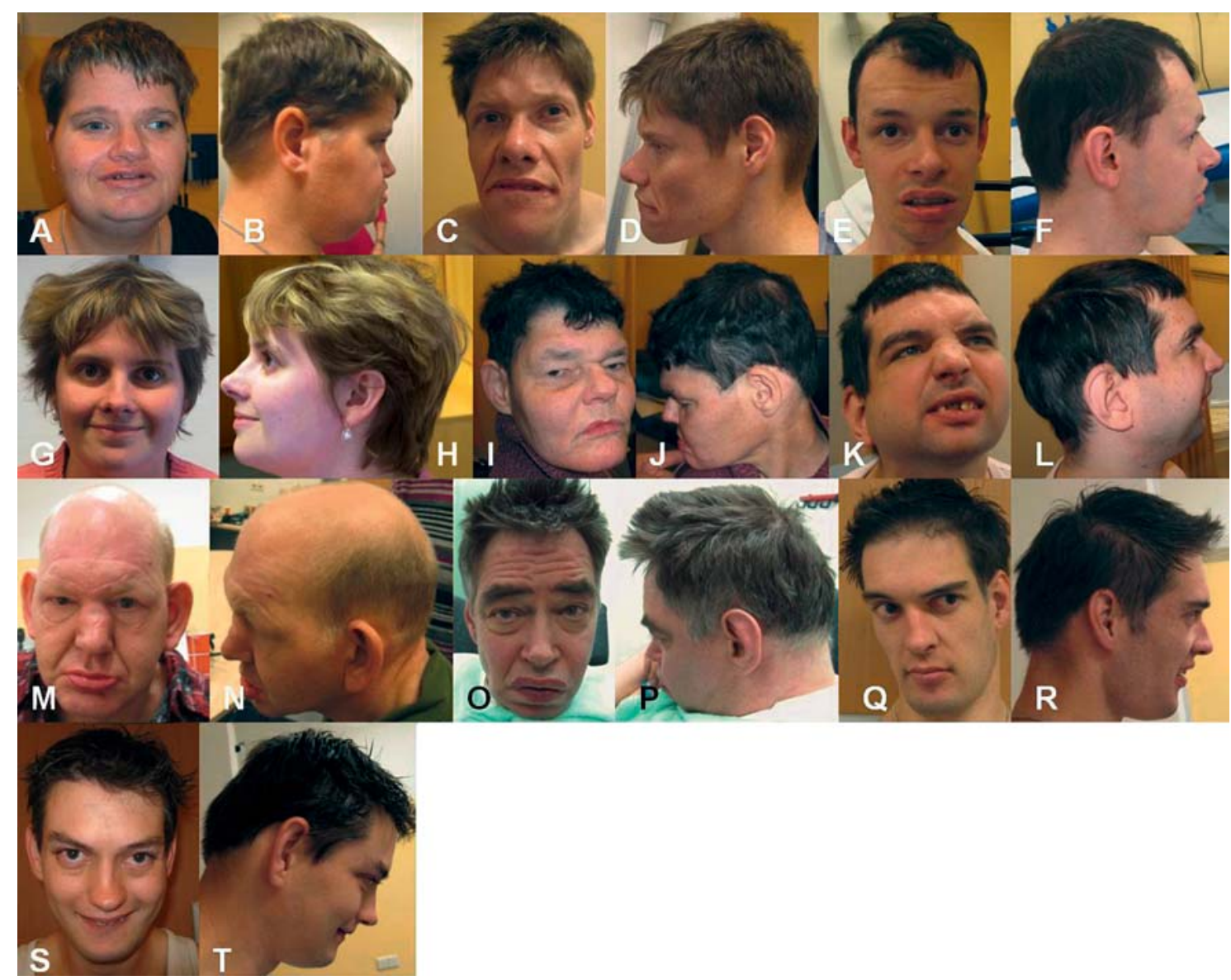

Fig. 1. Clinical pictures. A, B Typical facial features of Kleefstra syndrome in patient 1 . Note the midface hypoplasia, arched eyebrows and prognathism. C, D Typical facial appearance of Pitt Hopkins syndrome in patient 2. Note the coarse face with prognathism, broad mouth with down-turned corners and large nose. E, F Patient 3 with a mutation in MECP2 and his carrier sister $(\mathbf{G}, \mathbf{H}) . \mathbf{I}, \mathbf{J}$ Patient 4 with a mutation in CDKL5. Note her coarse face. K, L Patient 5 and $6(\mathbf{M}, \mathbf{N})$ with Dravet syndrome. O, P Patient 7 with Phelan-McDermid syndrome. Note the long face and full lips. Q-T Brother pair with Phelan-McDermid syndrome. Note the long face, prominent chin, and large ears in both brothers.

\section{Patient 3: Familial MECP2 Mutation}

This male patient was ascertained at the age of 27 years. Pregnancy and birth were uncomplicated. Birth weight was $3,750 \mathrm{~g}(50-75$ th centile). From the age of 24 months on his parents noticed a delay in his psychomotor development. He was able to walk independently between the age of 2 and 2.5 years and could speak a few single words. At the age of about 12 years he had developed tonic-clonic seizures. Seizures persisted on anti-epileptic drug treatment with a frequency of 1-2 times a day. Cerebral imaging by a CT scan at that time and later at adult age by MRI revealed no abnormalities. At adult age, his total IQ level as assessed by the WISC was 33 . His behavior was characterized by a lack of initiative and he was very calm, introverted, and friendly. He had features of autism spectrum disorder and periodic tics. Since his early twenties, he showed a progressive decline in general functioning, including loss of speech (he was able to talk in 2-3 word sentences before), progressive neurological symptoms including walking difficulties with frequent falling, tremors of both arms, and apathy (showing significantly less initiative than before). He needed more help in self care as well. During the nights he frequently awakened and wandered around. After the start of antidepressive drug treatment, he seemed to improve a little but did not regain his former level of functioning. On physical examination at the age of 27 years he had a height of $176 \mathrm{~cm}$ (16th centile), a weight of $51.5 \mathrm{~kg}$ (2nd centile), 
and a head circumference of $57 \mathrm{~cm}$ (25-50th centile). He had a mild brachycephaly and a long face with a pronounced chin. Other dysmorphic features included a full upturned tip of the nose and a broad mouth with full lips and everted lower lip (fig. 1E, F). He had narrow feet and hands with slender digits. His muscular tone was generally slightly increased and the reflexes were symmetrically brisk. There was a generalized muscular atrophy and a tremor of the arms.

The family history mentioned learning disabilities in the mother and his 3-year younger sister. The mother was admitted to a psychiatric hospital because of severe psychiatric problems. His sister had followed special education. At the age of 24 years she was employed as a packer at a distribution office and lived independently together with her husband. On physical examination she had a height of $167 \mathrm{~cm}$ (25th centile), a weight of 76 $\mathrm{kg}$ (90th centile), and a head circumference of $54.3 \mathrm{~cm}$ (20th centile). She had no evident dysmorphic features (fig. 1G, H).

Chromosomal analysis by 250k SNP array analysis and screening metabolic tests revealed no abnormalities. Because of the deterioration in functioning, neurological symptoms, and a family history suggestive for an Xlinked inheritance pattern, mutation analysis of both $A R X$ and MECP2 was performed. This revealed a pathogenic hemizygous late truncating mutation in MECP2 (c.1233_1243del, p.Ser411fs). Segregation analysis showed an identical heterozygous mutation in the sister. The mother was not available for testing.

\section{Patient 4: Rett Syndrome Variant with Infantile Spasms (CDKL5)}

This female patient was diagnosed at the age of 47 years. Pregnancy and birth were uncomplicated. She was doing well for the first 6 months, but then developed seizures and since then she had a delay in psychomotor development. Her motor development was only mildly delayed; however, she never learnt to speak. At adult age her ID was profound. The seizures persisted during her life, and despite treatment with multiple anti-epileptic drugs she suffered from frequent (atonic) seizures. In addition, she developed a mild spasticity. She had a friendly personality, and her behavior was characterized by hyperactivity, self-mutilation, and no sense of fear. At the age of 40 years a cerebral CT-scan, which was done because of a fall from a horse, showed signs of hypoplasia of the corpus callosum. The family history documented ID due to rhesusantagonism in 2 sons from 2 different brothers from the father. Upon

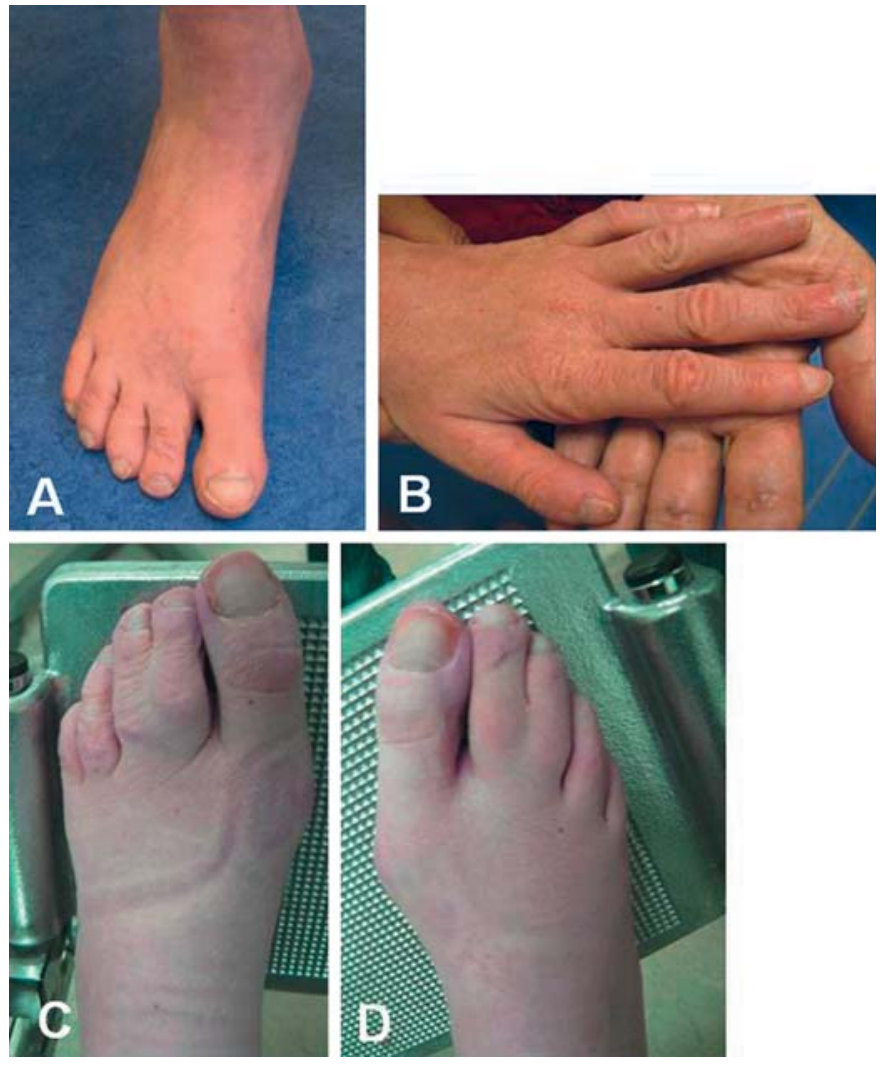

Fig. 2. Clinical pictures. A, B Clubbing of toe- and fingernails in patient 2 with a mutation in TCF4. C, D 2-3 toe syndactyly in patient 7 who was diagnosed with Phelan-McDermid syndrome.

physical examination at the age of 47 years she had a height of $162.5 \mathrm{~cm}(<16 \mathrm{th}$ centile), a weight of $45 \mathrm{~kg}$ (2nd centile), and a head circumference of $53 \mathrm{~cm}(<16$ th centile). She had prominent cheekbones, a mild prognathism, deep-set eyes, and blepharochalasis. The ears seemed to be slightly high positioned and she had a full upturned nose with hypertrophic alae nasi. The lips were full, and she missed several teeth due to caries (fig. 1I, J). She had thin limbs and small hands. Her feet showed slight clino- and syndactyly of the second and third toes. Chromosomal analysis by 250k SNP array analysis was normal, and screening metabolic tests revealed no abnormalities. Because of the severe ID combined with persistent therapy resistant seizures and the Rett syndrome-like phenotype, mutation analysis of MECP2, CDKL5, FOXG1, and SCN1A was performed, and a pathogenic splice site mutation in intron 7 of CDKL5 was found (c.464-1G>A). Segregation analysis in the parents was not performed. 


\section{Patients 5 and 6: Dravet Syndrome (SCN1A)}

\section{Patient 5}

This male patient was diagnosed at the age of 34 years. He was born at term after an uncomplicated pregnancy and birth. Birth weight was 4,000 g (<90th centile). He was doing well for the first 5 months but then developed seizures after a vaccination. Since then he had regular absences but developed normally according to his parents. At the age of 2 years seizure frequency increased and his speech gradually declined. At 3 years of age he had a status epilepticus followed by a coma state of several days. After awakening he had a severely retarded psychomotor function and furthermore a right hemiplegia and was no longer able to sit or walk. Gradually the hemiplegia partially recovered and he learnt to walk again, though he did not regain the ability to speak. The epilepsy persisted throughout his life and he suffered from intractable seizures (for which he wore a helmet) despite treatment with multiple anti-epileptic drugs. At adult age he had a profound ID (age equivalent 10-18 months). His behavior was very friendly and characterized by little initiative, obsessive traits, and self-mutilation (pulling out his nails). He had a very high threshold of pain. He recurrently had upper and lower airway infections. Upon physical examination at the age of 34 years his height was $193 \mathrm{~cm}$ (90th centile), weight $84 \mathrm{~kg}$ ( $>50$ th centile), and head circumference $59 \mathrm{~cm}$ (80th centile). He had a slight micrognathia and several scars on his face due to recurrent epileptic falls. The ears were large and the lips full, but his appearance was not quite dysmorphic (fig. $1 \mathrm{~K}, \mathrm{~L}$ ). He was able to walk but he was somewhat hindered in his motor function by a mild right-sided hemiplegia. Chromosomal analysis by 250k SNP array analysis was normal, and screening metabolic tests revealed no abnormalities. Because of the severe ID and intractable seizures, mutation analysis of SCN1A was performed and revealed a pathogenic mutation in exon 26 (c.5304T $>$ G, p.Ser1768Arg). Segregation analysis in the parents showed that the mutation had occurred de novo.

\section{Patient 6}

This patient was ascertained at the age of 49 years. Pregnancy and birth were uneventful. He developed seizures after vaccination at about 6 months of age. His psychomotor development was delayed. Motor milestones were only mildly delayed according to his brother. Speech development was more severely delayed, and he only learnt to speak a single word. At adult age he had a severe ID but had a good mobility. The epilepsy (mixed seizures) persisted throughout his life despite treatment with mul- tiple anti-epileptic drugs. Seizures were provoked by psychological stress and constipation. He had a friendly personality and loved to get attention. Ophthalmological evaluation revealed a high hypermetropia and a substantial astigmatism. The family history of the mother was positive for epilepsy without developmental delay. At the age of 36 years conventional karyotyping and tests for Fragile X syndrome and Angelman syndrome were all normal. Upon physical examination at the age of 49 years his height was $175 \mathrm{~cm}$ (10th centile), weight $72.5 \mathrm{~kg}$ (84th centile), and head circumference $57.4 \mathrm{~cm}(<50$ th centile). He had minor facial dysmorphism including a high forehead, large lop ears, a prominent philtrum, and a full lower lip. His teeth had been removed because of caries (fig. 1M, N). On the feet he had a clinodactyly of the second toe and a cutaneous syndactyly of the second and third toes. His motor function was clumsy and he had mild spasticity. Chromosomal analysis by $250 \mathrm{k}$ SNP array analysis and screening metabolic tests revealed no abnormalities. Because of his severe ID and intractable seizures, mutation analysis of $S C N 1 A$ was performed and revealed a frameshift mutation in exon 7 leading to a premature stop codon (c.3526delG, p.Glu1176fs). Parents were not available for segregation analysis.

\section{Patients 7, 8, and 9: Phelan-McDermid}

Syndrome (22qter Deletion)

\section{Patient 7}

This male patient was ascertained at the age of 48 years. He was born as the fifth child of his parents. Pregnancy, delivery, and perinatal period were not remarkable. During his second year, his parents noticed a delay in his psychomotor development. He learnt to walk significantly later than his siblings, but his speech did not develop. At adult age his ID was severe. His behavior was not remarkable, and he had good social interactions. An abnormal breathing pattern, including intermittent irregular and rapid breathing was observed. At the age of 27 years he was diagnosed with hyperthyroidism, and treatment with Strumazol and Thyrax was started, but otherwise his general health was good. His vision was reported to be mildly impaired due to mild myopia and a slightly limited visual field of unknown cause. Since the age of 45 years his general functioning had declined remarkably after a hospital admission because of severe pneumonia complicated by respiratory insufficiency. He was no longer able to walk, had feeding problems due to swallowing difficulties, and became dependent on tube feeding. Contact making and social interaction diminished, and he also developed seizures. Cerebral imaging 
by both CT scan and MRI scan showed normal brain anatomy apart from mild enlargement of the cisterna magna and central atrophy. At the age of 49 years he died from pneumonia. The family history reported mild learning and behavior problems in an older sister and severe intellectual and physical disability in a son of a brother of the father.

Upon physical examination at the age of 48 years his height was on the 50th centile. Head circumference and weight were on the 80th centile. Facial appearance was coarse with bushy eyebrows, a short philtrum, a broad mouth with very full lips and widely placed dentition and he had large ears (fig. 1O, P). He had evident syndactyly of the second and third toes, with a nearly complete fusion on the right side (fig. 2C, D). He was wheelchair dependent and showed hypertonia with spastic posture of the hands and feet. Genetic tests included chromosomal analysis by $2.7 \mathrm{M}$ SNP array analysis and mutation analysis of TCF4 because of clinical similarities with Pitt Hopkins syndrome. 2.7M SNP array analysis identified a $1.8-\mathrm{Mb}$ loss in chromosomal region 22q13.32q13.33 $(47,782,571-49,543,031 \mathrm{Mb})$. Parents were not available for chromosomal analysis. Mutation analysis of TCF4 revealed no abnormalities.

\section{Patients 8 and 9}

This brother pair was ascertained at the age of 31 and 29 years, respectively. Both were born after an uneventful pregnancy and delivery and had normal birth parameters. During the neonatal period the older brother (patient 8) was treated with phototherapy because of hyperbilirubinemia. He was a very quiet baby. Since birth he had a mild spasticity of his right leg. He was treated with splints because of inverted position of his ankles. His psychomotor development was delayed. He was able to sit and walk independently at the age of 12 and 24 months, respectively. Speech development was delayed, but he learnt to speak simple sentences. Since childhood he had intermittently high levels of bilirubin and was diagnosed with Gilbert syndrome. At child age he underwent a unilateral orchidopexy because of torsio testis, and his phimosis was corrected. At adult age he had a moderate to severe ID. He was diagnosed with a bipolar mood disorder. During depressive episodes he suffered from sleeping disorders and refused to eat. In general, his behavior was friendly, but regularly he showed an aggressive behavior. Social interaction was good. Upon physical examination at the age of 31 years he had a high normal height $(190 \mathrm{~cm}, 75$ th centile) and a normal weight (50th centile) and head circumference (20th centile). Hands and feet were large to normal. Facial characteristics included a long face with prominent chin and large ears (fig. 1Q, R). He had an increased lordosis of the lumbar spine which was suggestive for muscular hypotonia of the trunk. The feet were slightly inverted.

In contrast, the younger brother (patient 9) was a hyperactive baby with poor contact making. Since he was 2 months of age, his parents noticed that he developed abnormally. The motor development was mildly delayed with sitting independently at 13 months and walking independently at 20 months of age. Speech development was more severely delayed with the first single words at the age of 4 years. With age his social interaction improved, and he had good contact with his parents, brother, and care-takers; however, contact with housemates was limited. He showed mild features of autism spectrum disorder, including obsessive behaviors. His developmental level was somewhat lower than his brother's and corresponding with a developmental level of a 2-3-year-old child. His mood and behavior were changeable, including periods with hyperactivity and aggressive outbursts as well as periods with apathy. Now and then he had sleeping difficulties with awakening and wandering during the night. He was diagnosed with a bipolar mood disorder as well. At a young age he underwent an operation because of cryptorchidism and phimosis. His general health condition was good. Upon physical examination he had a normal height $(185 \mathrm{~cm}, 50$ th centile) and weight (50-75th centile) and a small head circumference on the 2nd centile $(54 \mathrm{~cm})$. He had a brachycephaly. Just as his brother he had a prominent chin and large ears. In addition, he had a left-sided epicanthal fold, a subtle bifid point of the nose and horizontal ear lobe creases (fig. 1S, T). He had a similar posture like his brother, including an increased lordosis of the lumbar spine.

In both brothers brain MRI showed hypoplasia of the cerebellar vermis, an enlarged cisterna magna, and mild enlargement of the lateral ventricles.

Chromosomal analysis by 250k SNP array analysis identified an identical terminal loss of $2.12 \mathrm{Mb}$ in chromosomal region 22q13.32q13.33 (47,35-49,47 Mb) in both brothers. Chromosomal analysis in blood lymphocytes from the parents both by SNP array analysis and FISH analysis, with probes localized on chromosomal regions $22 \mathrm{q} 11$ and $22 \mathrm{q} 13$, gave normal results. To further investigate the probability of the presence of the 22qter deletion in a mosaic pattern in one of the parents, we performed additional FISH experiments in buccal cells of the parents as well. Indications for a mosaic pattern in the parents were not found. 
Table 1. Clinical features in present and previously reported patients with (genetically confirmed) Kleefstra syndrome

\begin{tabular}{|c|c|c|c|c|c|c|}
\hline & Present patient & $\begin{array}{l}\text { Kleefstra } \\
\text { et al. [2006] }\end{array}$ & $\begin{array}{l}\text { Kleefstra et al. [2009] } \\
\text { ( } 2 / 6 \text { described in more detail in } \\
\text { Verhoeven et al. [2010]) }\end{array}$ & $\begin{array}{l}\text { Willemsen et al. } \\
\text { [this issue] ( } 2 / 4 \text { de- } \\
\text { scribed in more detail in } \\
\text { Verhoeven et al. [2011]) }\end{array}$ & Verhoeven et al. [2011] & Total \\
\hline Number of adults & 1 & 1 & 6 & $\begin{array}{l}4 \text { (excl. present } \\
\text { patient 1) }\end{array}$ & $\begin{array}{l}1 \text { (other } 2 \text { adults are } \\
\text { included in Willemsen } \\
\text { et al. [this issue]) }\end{array}$ & 13 \\
\hline Genetic defect & $\begin{array}{l}\text { EHMT1 mutation: } \\
\text { c. } 3087+1 \mathrm{G}>\mathrm{T}\end{array}$ & $\begin{array}{l}\text { micro- } \\
\text { deletion }\end{array}$ & $6 / 6$ microdeletion & $\begin{array}{l}\text { 3/4 microdeletion, } \\
\text { 1/4 EHMT mutation }\end{array}$ & microdeletion & $\begin{array}{l}\text { 11/13 microdeletion } \\
\text { 2/13 EHMT1 mutation }\end{array}$ \\
\hline Age, years & 41 & 36 & $20-59$ & $18-32$ & 19 & $18-59$ \\
\hline Gender & $\mathrm{f}$ & $\mathrm{f}$ & $4 \mathrm{~m}, 2 \mathrm{f}$ & $3 \mathrm{f}, 1 \mathrm{~m}$ & $\mathrm{f}$ & $5 \mathrm{~m}, 8 \mathrm{f}$ \\
\hline $\begin{array}{l}\text { Developmental } \\
\text { outcome }\end{array}$ & $\begin{array}{l}\text { moderate ID, } \\
\text { some speech }\end{array}$ & severe ID & $6 / 6$ variable ID & moderate-severe ID & moderate ID & $\begin{array}{l}13 / 13 \text { moderate-severe } \\
\text { ID }\end{array}$ \\
\hline Motor symptoms & $\begin{array}{l}\text { focal myclonic twitches } \\
\text { shoulder, fixed flexure } \\
\text { arms and hands }\end{array}$ & NR & $\begin{array}{l}1 / 2 \text { progressively immobile } \\
1 / 2 \text { frequent myoclonic twitches, } \\
\text { slight hypertonia } \\
\text { fixed flexure arms and hands in } 2 / 2\end{array}$ & $\begin{array}{l}1 / 4 \text { rigid flexure of the } \\
\text { arms and hands }\end{array}$ & $\begin{array}{l}\text { slow, preservative and } \\
\text { clumsy motor func- } \\
\text { tioning at adult age }\end{array}$ & $\begin{array}{l}\text { myoclonic twitches in } \\
2 \text { patients; immobility in } \\
1 \text { patient; fixed flexure } \\
\text { extremities in } 4 \text { patients }\end{array}$ \\
\hline $\begin{array}{l}\text { Regression (of psy- } \\
\text { chomotor function) }\end{array}$ & + & NR & $3 / 5$ & $1 / 4$ & + & $6 / 11$ \\
\hline Behavior/psychiatric & $\begin{array}{l}\text { impulsivity and aggres- } \\
\text { sive outbursts; around } \\
\text { age } 38 \text { remarkable be- } \\
\text { havior change: periods } \\
\text { of apathy, decreased } \\
\text { emotional responsive- } \\
\text { ness, staring, low motor } \\
\text { activity, stupor, and } \\
\text { sleep disturbance }\end{array}$ & $\begin{array}{l}+, \text { not further } \\
\text { specified }\end{array}$ & $\begin{array}{l}2 / 5 \text { aggression } \\
2 / 5 \text { sleep disturbance } \\
3 / 5 \text { passive periods } \\
2 / 5 \text { mood disorder } \\
2 / 2 \text { stereotypic orofacial movements } \\
3 / 5 \text { increase of behavior problems/ } \\
\text { temporary regression during teenage } \\
\text { years } \\
\text { 2/2 during midlife occurrence of } \\
\text { bizarre and distinct posture, } \\
\text { hypoactivity, minimal emotional } \\
\text { response, lack of initiative, and staring }\end{array}$ & $\begin{array}{l}1 / 4 \text { sleep disturbance } \\
1 / 4 \text { stereotypies } \\
2 / 4 \text { mood disorder } \\
1 / 4 \text { hyperactivity } \\
1 / 4 \text { increase of behavior } \\
\text { problems during } \\
\text { teenage years with } \\
\text { progressive inactivity } \\
\text { and catatonic features } \\
\text { g }\end{array}$ & $\begin{array}{l}\text { sleep disturbance; } \\
\text { increase of behavior } \\
\text { problems in adolescence } \\
\text { with later on general } \\
\text { inactivity and irritability, } \\
\text { stereotypies }\end{array}$ & $\begin{array}{l}\text { variable behavior prob- } \\
\text { lems in all; temporary } \\
\text { (behavioral) regression/ } \\
\text { increase of behavioral } \\
\text { problems during adoles- } \\
\text { cence; onset of typical } \\
\text { behavior pattern at mid- } \\
\text { dle age including periods } \\
\text { with passivity, decreased } \\
\text { responsiveness and } \\
\text { hypoactivity in a subset }\end{array}$ \\
\hline Seizures & - & + & $4 / 6$ & $2 / 4$ & - & $7 / 13$ \\
\hline $\begin{array}{l}\text { Recognizable facial } \\
\text { features }\end{array}$ & + & + & + & + & + & present in all \\
\hline $\begin{array}{l}\text { Medical problems, } \\
\text { age of onset } \\
\text { (when documented) }\end{array}$ & $\begin{array}{l}\text { hypertrophy of the } \\
\text { left ventricle and } \\
\text { paroxysmal atrial } \\
\text { fibrillation, diagnosed } \\
\text { around age } 40 \text { years }\end{array}$ & NR & $\begin{array}{l}1 / 6 \text { scoliosis } \\
1 / 6 \text { severe GOR with weight loss } \\
1 / 6 \text { pyloric stenosis } \\
1 / 6 \text { death with unknown cause at } \\
\text { age } 21\end{array}$ & $\begin{array}{l}2 / 4 \text { frequent respiratory } \\
\text { infections/aspiration } \\
1 / 4 \text { mild pulmonic re- } \\
\text { gurgitation as an adult } \\
1 / 4 \text { scoliosis }\end{array}$ & $\begin{array}{l}\text { ventricular septum } \\
\text { defect }\end{array}$ & $\begin{array}{l}3 / 12 \text { cardiac } \\
2 / 12 \text { scoliosis } \\
2 / 12 \text { gastro-intestinal } \\
1 / 12 \text { early death } \\
2 / 12 \text { recurrent } \\
\text { respiratory problems }\end{array}$ \\
\hline \multicolumn{7}{|c|}{ Adult growth parameters } \\
\hline height & normal & NR & $2 / 4$ short stature & $2 / 4$ short stature & $5 / 10$ short stature & $5 / 10$ short stature \\
\hline weight & obesity & obesity & $1 / 5$ obesity & 1/4 obesity & $5 / 12$ obesity & $5 / 12$ obesity \\
\hline Other & $\begin{array}{l}\text { brain MRI: poorly } \\
\text { defined abnormal white } \\
\text { matter signal intensities, } \\
\text { manly localized deep in } \\
\text { the parietal lobe, } \\
\text { bilaterally abnormal } \\
\text { signal intensity in the } \\
\text { globus pallidus }\end{array}$ & brachydactyly & $\begin{array}{l}1 / 6 \text { hearing loss } \\
2 / 6 \text { cryptorchidism } \\
1 / 6 \text { VUR } \\
3 / 5 \text { minor anomalies on brain MRI: } \\
1 / 5 \text { small pons, } 1 / 5 \text { prominent } \\
\text { Virchow-Robin spaces, } \\
1 / 5 \text { asymmetry of anterior horns }\end{array}$ & $\begin{array}{l}1 / 4 \text { hearing loss } \\
1 / 4 \text { brachydactyly } \\
1 / 4 \text { hyperopia } \\
1 / 4 \text { cryptorchidism } \\
1 / 3 \text { white matter le- } \\
\text { sions, corpus callosum } \\
\text { hypoplasia }\end{array}$ & - & $\begin{array}{l}5 / 10 \text { variable anomalies } \\
\text { on brain MRI }\end{array}$ \\
\hline
\end{tabular}

$\mathrm{NR}=$ Not reported; GOR = gastro-oesophageal reflux; VUR = vesicoureteral reflux.

\section{Evolution of Phenotypes in Present and Previous \\ Cases}

Kleefstra Syndrome. Adult patients with Kleefstra syndrome have rarely been reported before [Kleefstra et al.,
2006, 2009; Verhoeven et al., 2010, 2011; Willemsen et al., this issue]. Table 1 summarizes the phenotypic features of the present and 12 previously reported adult patients diagnosed with Kleefstra syndrome. Developmental out- 
Table 2. Clinical features in present and previously reported patients with (genetically confirmed) Pitt Hopkins syndrome

\begin{tabular}{|c|c|c|c|c|c|}
\hline & Present patient & Zweier et al. [2007] & Zweier et al. [2008] & Rosenfeld et al. [2009] & Total \\
\hline Number of adults & 1 & 2 & 3 & 1 & 7 \\
\hline Genetic defect & $\begin{array}{l}\text { TCF4 mutation: } \\
\text { c. } 1739 \mathrm{G}>\mathrm{A}\end{array}$ & $\begin{array}{l}\text { TCF4 mutations: } \\
\text { c. } 1153 \mathrm{C}>\mathrm{T} \text { and IVS9-1G }>\mathrm{C}\end{array}$ & $\begin{array}{l}\text { TCF4 mutations: } \\
\text { c. } 1699 \mathrm{~A}>\mathrm{T}, \mathrm{c} .469 \mathrm{C}>\mathrm{T}, \\
\text { c. } 1073 \mathrm{G}>\mathrm{T}\end{array}$ & 64-kb microdeletion $18 \mathrm{q} 21.2$ & $\begin{array}{l}6 \text { TCF4 mutations, } \\
1 \text { small microdeletion }\end{array}$ \\
\hline Age, years & 40 & 29 & $18-20$ & 19 & $18-40$ \\
\hline Developmental outcome & severe ID & severe ID & severe ID & severe ID & severe ID \\
\hline Motor symptoms & mild hypertonia & $\begin{array}{l}1 / 2 \text { ataxia } \\
1 / 2 \text { wide-based walking pattern }\end{array}$ & $1 / 3$ ataxia & walks with assistance & $2 / 7$ ataxia, $1 / 7$ hypertonia \\
\hline $\begin{array}{l}\text { Regression } \\
\text { (of psychomotor function) }\end{array}$ & - & NR & NR & NR & never reported \\
\hline Behavior/psychiatric & happy disposition, pica & $\begin{array}{l}1 / 2 \text { very anxious, } \\
\text { self-mutilation }\end{array}$ & $\begin{array}{l}2 / 3 \text { happy disposition } \\
1 / 3 \text { violent outburst, } \\
\text { stereotypies }\end{array}$ & $\begin{array}{l}\text { happy disposition, bangs on } \\
\text { objects, sleeping problems }\end{array}$ & $\begin{array}{l}\text { mostly happy disposition, } \\
\text { but diverse behavior } \\
\text { problems do also occur }\end{array}$ \\
\hline Seizures & - & - & $1 / 3$, since 9 months of age & - & $2 / 7$, onset during childhood \\
\hline Recognizable facial features & + & + & $\begin{array}{l}2 / 3+ \\
1 / 3+/-\end{array}$ & + & $7 / 7$ \\
\hline $\begin{array}{l}\text { Medical problems, age of } \\
\text { onset (when documented) }\end{array}$ & $\begin{array}{l}\text { myopia, scoliosis, } \\
\text { osteoporosis and atopic } \\
\text { constitution, onset in } \\
\text { childhood }\end{array}$ & $\begin{array}{l}1 / 2 \text { severe constipation, } \\
\text { and strabismus in onset NR } \\
1 / 2 \text { lymphoma and dislocated } \\
\text { hip, onset NR }\end{array}$ & $\begin{array}{l}2 / 3 \text { constipation, scoliosis } \\
1 / 3 \text { myopia, strabismus }\end{array}$ & strabismus, myopia & $\begin{array}{l}\text { constipation, scoliosis, and } \\
\text { aspecific ocular problems in } \\
\text { several patients }\end{array}$ \\
\hline $\begin{array}{l}\text { Adult growth parameters } \\
\text { head circumference }\end{array}$ & P0.6 & $2 / 2<\mathrm{P} 3$ & $2 / 3<\mathrm{P} 3,1 / 3$ normal & P50 & 5/7 microcephaly \\
\hline height & $>\mathrm{P} 2$ & $2 / 2<\mathrm{P} 3$ & NR & P10-25 & 3/4 short stature \\
\hline weight & P16 & $2 / 2<\mathrm{P} 3$ & NR & P60 & 2/4 underweight \\
\hline Abnormal breathing pattern ${ }^{a}$ & - & $2 / 2$ & $2 / 3$ & + , breath holding & $5 / 7$ \\
\hline Other & $\begin{array}{l}\text { finger- and toenail } \\
\text { clubbing }\end{array}$ & $\begin{array}{l}\text { finger- and toenail clubbing } \\
\text { in } 1 / 2\end{array}$ & NR & NR & $2 / 3$ nail clubbing \\
\hline
\end{tabular}

$\mathrm{NR}=$ Not reported; $\mathrm{P}=$ percentile. ${ }^{\mathrm{a}}$ Comprising periods with hyperventilation followed by apnoea.

come varied from moderate to severe ID. Most patients have little speech ability, though mostly very primitive. Six out of 11 patients (in 2 patients a presence of regression was not reported) showed some kind of regression during adolescence or adulthood, which was in 5 patients reported to be associated with a concurrent striking behavioral change including periods of diminished responsiveness, hypoactivity, passivity, and catatonic phenomena. Seven out of 13 had (a history of) seizures, though in general not very severe. All adult patients had the typical facial features of Kleefstra syndrome. In the present patient the facial features were the major clue to the diagnosis in addition to the characteristic regressive behavioral pattern with onset at adult age. Microcephaly was present in 5 out of 13 patients, 5 out of 10 had a short adult height, and 5 out of 12 patients presented with obesity. In conclusion, most important diagnostic clues at adult age seem to be the typical facial features and behavior pattern which might be associated with regression of general functioning.
Pitt Hopkins Syndrome. The present patient is the oldest reported patient with Pitt Hopkins syndrome. As far as we know, 6 adult patients with genetically confirmed Pitt Hopkins syndrome have been reported in previous studies (table 2). All adults with Pitt Hopkins syndrome had a severely impaired developmental outcome. A minority suffered from seizures that presented at childhood. Late-onset seizures were not reported, suggesting that if seizures develop, they present at a young age. Medical problems were relatively mild, including mainly constipation, scoliosis, and aspecific ocular problems. Motor functioning was mildly impaired in some cases. Reported behavioral problems are diverse, but most patients have a happy disposition. Among this small group of adults with Pitt Hopkins syndrome, there are no indications for significant regression at adult age. The typical facial characteristics persist during adult age. In the present patient his facial gestalt was the clue to the diagnosis. In general, the combination of the typical facial characteristics, severe ID, the breath- 
ing pattern with periods of hyperventilation followed by apnoea, and the clubbing of finger- and toenails might suggest the diagnosis Pitt Hopkins syndrome in adults.

MECP Mutations in Males. MECP2 mutations are involved in Rett syndrome. Initially, it was thought that Rett syndrome occurs exclusively in females due to lethality of hemizygous mutations in males. Though, after the identification of the MECP2 gene in 1999, several MECP2 mutations have been detected in males as well. The phenotypic variability in males with MECP2 mutations is wide, and roughly 3 groups of phenotypes can be observed: (a) classical/atypical Rett syndrome occurring in males with a classical Rett syndrome mutation in mosaic pattern or in males with an XXY karyotype, (b) severe congenital encephalopathy, mostly associated with a mutation that causes Rett syndrome in females, and (c) a broad group with a wide phenotypic spectrum including variable levels of ID and variable occurrence of other neurological and/or psychiatric disorders [Moog et al., 2003, 2006; Villard, 2007]. The phenotypes caused by $M E C P 2$ duplications are not considered here. Mutations that cause the classical Rett syndrome phenotype in females are considered to be either prenatally lethal in males or leading to severe congenital encephalopathy and early death [Schüle et al., 2008]. The present patient can be assigned to the third group. Several males from $\mathrm{X}$-linked ID families and single male patients with a phenotype fitting in the third group have been reported before [Meloni et al., 2000; Orrico et al., 2000; Couvert et al., 2001; Yntema et al., 2002]. Frameshift/truncating mutations, as observed in the present patient, infrequently have been reported in males before ( 2 previous reports) [Kleefstra et al., 2002; Moog et al., 2003]. Adult phenotypes of present and 23 previous cases are summarized in table 3 . All patients (age range $21-56$ years) have an impaired developmental outcome, though varying from mild to profound ID. From these data a significant phenotype-genotype correlation with respect to the degree of ID cannot be observed. In 2 of the families reported, identical mutations lead to a developmental level varying from mild to severe disability [Gendrot et al., 1999; Couvert et al., 2001; Gomot et al., 2003]. Almost all patients showed evident motor/neurological symptoms as tremors (46\%), pyramidal signs (58\%), and in 2 patients ataxic signs were observed. Interestingly, in one family tremors were reported in the carrier females as well [Couvert et al., 2001; Gomot et al., 2003]. Almost $30 \%$ of the males showed regression in functioning at adult age. One third of the patients had seizures, and with the exception of one, onset was reported at child- hood age. A majority (64\%) had microcephaly and short stature (67\%). Four out of 24 developed kyphosis/scoliosis with age. Many were reported to have a friendly and cooperative behavior, though a few patients showed aggressive outbursts. Mood/depression and anxiety disorders were frequently observed. A subset of the patients had a passive, inactive personality, and some were shy/ introverted in social interaction. In conclusion, clue features that might indicate the presence of a MECP2 mutation in adult males are variable ID in combination with neurological symptoms, including pyramidal signs and tremors, mood and anxiety disorders, and possibly regression at adult age. Facial features are not remarkable and do not contribute to the diagnosis.

Rett Syndrome Variant with Infantile Spasms (CDKL5 Mutations). The present patient is the oldest patient with a mutation in CDKL5 reported. Table 4 summarizes the clinical features of the present and 9 other adult female patients [Tao et al., 2004; Weaving et al., 2004; Archer et al., 2006; Bahi-Buisson et al., 2008a, b; Erez et al., 2009]. The developmental outcome is very poor. Remarkably, in one patient (twin sister of a severely affected patient) the developmental level was reported to be only mildly impaired [Weaving et al., 2004]. Six out of 10 patients were not able to speak. All patients showed motor symptoms, including mostly pyramidal signs, but also cerebellar symptoms were reported. Secondary locomotor tract deformities including scoliosis and/or contractures were present in 6 out of 8 patients. Five out of 9 patients had signs of autonomic dysregulation (intestinal symptoms, breathing anomalies, and vasomotor disturbance). Regression was reported in 4 out of 10 patients. Seizure outcome was very poor. Nine patients suffered from persistent intractable seizures into adulthood. Behavior characteristics that were frequently present included (hand)stereotypies and poor social interaction. Sleeping problems were documented in $4 \mathrm{pa}-$ tients. Small hands and/or feet were also more often reported (4/7). In conclusion, the consistent clinical features at adult age included a very poor developmental and seizure outcome in combination with other neurological signs including pyramidal tract and cerebellar and autonomic signs. Major health problems were secondary to neurological problems. Behavior symptoms included Rett-like behaviors such as (hand) stereotypies.

Dravet Syndrome. In contrast to the other reported syndromes in the present study, follow-up of Dravet syndrome patients into adulthood has more often been documented before [Jansen et al., 2006; Akiyama et al., 2010]. The phenotype of 37 adult patients, including the 
Table 3. Clinical features of present and previously reported male patients with 'mild' MECP 2 mutations that do not cause classical Rett syndrome in female patients or severe neonatal encephalopathy/prenatal death in males

\begin{tabular}{|c|c|c|c|c|c|c|c|c|}
\hline & Present patient & $\begin{array}{l}\text { Gendrot et al. [1999]; } \\
\text { Couvert et al. [2001]; } \\
\text { Gomot et al. [2003] } \\
\text { (MRX16) }\end{array}$ & $\begin{array}{l}\text { Gomot et al. [2003]; } \\
\text { Yntema et al. [2002] } \\
\text { (T44) }\end{array}$ & $\begin{array}{l}\text { Couvert et al. [2001]; } \\
\text { Gomot et al. [2003] } \\
\text { (T36) }\end{array}$ & $\begin{array}{l}\text {; Orrico et al. } \\
{[2000]} \\
\text { (X307, MR48, } \\
\text { MR50, X308) }\end{array}$ & $\begin{array}{l}\text { Lindsay et al. [1996]; } \\
\text { Klauck et al. [2002] }\end{array}$ & $\begin{array}{l}\text { Meloni et al. [2000]; } \\
\text { Claes et al. [1997] }\end{array}$ & Total \\
\hline Number of adults & 1 & 7 & 3 & 4 & 4 & 4 & 1 & 24 \\
\hline $\begin{array}{l}\text { Mutation/ } \\
\text { domain }\end{array}$ & $\begin{array}{l}\text { frameshift: } \\
\text { c.1233_1243del } \\
\text { (p.Ser411fs)/ } \\
\text { C-terminus }\end{array}$ & $\begin{array}{l}\text { missense: } \\
\text { c.410A }>\mathrm{G} \\
\text { (p.Glu137Gly)/ } \\
\text { MBD }\end{array}$ & $\begin{array}{l}\text { in frame deletion } \\
\text { c.1161_1400del/ } \\
\text { C-terminus }\end{array}$ & $\begin{array}{l}\text { missense: c. } 499 \mathrm{C}>\mathrm{T} \\
\text { (p.Arg167Trp)/ } \\
\text { Co-repressor } \\
\text { interacting region }\end{array}$ & $\begin{array}{l}\text { missense: c. } 493 \\
\mathrm{C}>\mathrm{T} \text { (p. Ala- } \\
\text { 140Val)/MBD }\end{array}$ & $\begin{array}{l}\text { missense: } \\
\text { c. } 493 \mathrm{C}>\mathrm{T} \\
\text { (p.Ala140Val)/ } \\
\text { BD }\end{array}$ & $\begin{array}{l}\text { nonsense: } \\
\text { c.1216 C>T } \\
\text { (p.Glu406X)/ } \\
\text { C-terminus }\end{array}$ & $\begin{array}{l}\text { 19/24 missense } \\
1 / 24 \text { nonsense, } \\
1 / 24 \text { frameshift, } \\
3 / 24 \text { in frame } \\
\text { deletion } \\
5 / 24 \text { in MBD } \\
5 / 24 \text { in C-terminus } \\
4 / 24 \text { in co-repres- } \\
\text { sor interacting } \\
\text { region }\end{array}$ \\
\hline Age, years & 27 & $21-56$ & $24-55$ & $25-50$ & $27-40$ & $25-41$ & 39 & $21-56$ \\
\hline $\begin{array}{l}\text { Developmental } \\
\text { outcome }\end{array}$ & severe ID & $\begin{array}{l}6 / 7 \text { mild/ } \\
\text { moderate ID } \\
1 / 7 \text { profound ID }\end{array}$ & $\begin{array}{l}1 / 3 \text { mild ID } \\
1 / 3 \text { moderate ID } \\
1 / 3 \text { severe ID }\end{array}$ & 4/4 mild ID & $4 / 4$ severe ID & $4 / 4$ moderate ID & severe ID & $24 / 24$ variable ID \\
\hline $\begin{array}{l}\text { Motor } \\
\text { symptoms }\end{array}$ & $\begin{array}{l}\text { mild spasticity, } \\
\text { hypertonia, } \\
\text { brisk reflexes, } \\
\text { generalized mus- } \\
\text { cular atrophy; } \\
\text { frequent falling; } \\
\text { resting tremor }\end{array}$ & $\begin{array}{l}\text { 5/6 hyperreflexia } \\
\text { (1 NR) }\end{array}$ & $1 / 3$ hypertonia & $\begin{array}{l}3 / 4 \text { resting tremor } \\
3 / 4 \text { hyperreflexia } \\
1 / 4 \text { ataxia }\end{array}$ & $\begin{array}{l}4 / 4 \text { resting } \\
\text { tremor }\end{array}$ & $\begin{array}{l}3 / 4 \text { resting tremor } \\
3 / 4 \text { hyperreflexia } \\
2 / 4 \text { hypertonia }\end{array}$ & $\begin{array}{l}\text { spasticity, } \\
\text { hyperreflexia, } \\
\text { choreoathetotic } \\
\text { movemements, } \\
\text { ataxic gait }\end{array}$ & $\begin{array}{l}11 / 24 \text { tremor } \\
14 / 24 \text { pyramidal } \\
\text { signs } \\
2 / 24 \text { ataxia }\end{array}$ \\
\hline $\begin{array}{l}\text { Regression } \\
\text { (of psycho- } \\
\text { motor function) }\end{array}$ & $\begin{array}{l}+ \text {, global decline } \\
\text { since early } \\
\text { twenties }\end{array}$ & $\begin{array}{l}4 / 6 \text { language } \\
\text { regression }\end{array}$ & - & $\begin{array}{l}1 / 4 \text { deterioration } \\
\text { of articulation }\end{array}$ & - & - & $\begin{array}{l}+, \text { around age } 30 \\
\text { motor decline/ } \\
\text { progressive spasticity }\end{array}$ & $7 / 24$ \\
\hline $\begin{array}{l}\text { Behavior/ } \\
\text { psychiatric }\end{array}$ & $\begin{array}{l}\text { passivity, lack } \\
\text { of initiative, } \\
\text { cooperative, } \\
\text { calm, shy and } \\
\text { friendly; de- } \\
\text { pression, sleep } \\
\text { disturbance }\end{array}$ & $\begin{array}{l}\text { 4/7 introvert/ } \\
\text { timid/shy } \\
3 / 7 \text { anxiety } \\
\text { 2/7 passivity/ } \\
\text { slowness }\end{array}$ & $\begin{array}{l}1 / 3 \text { irritability, } \\
\text { depression, emotional } \\
\text { disturbance } \\
1 / 3 \text { poor contact and } \\
\text { violence } \\
1 / 3 \text { shy, quiet, anxious, } \\
\text { and attention problems }\end{array}$ & $\begin{array}{l}3 / 4 \text { pleasant } \\
1 / 4 \text { aggression } \\
1 / 4 \text { anxiety } \\
\\
\text { s }\end{array}$ & slow, friendly & $\begin{array}{l}3 / 4 \text { depression } \\
2 / 4 \text { aggression }\end{array}$ & NR & $\begin{array}{l}6 / 23 \text { shy/timid } \\
10 / 23 \text { mood/ } \\
\text { anxiety disorder } \\
4 / 23 \text { aggression } \\
4 / 23 \text { passivity/ } \\
\text { hypoactivity }\end{array}$ \\
\hline Seizures & $\begin{array}{l}+ \text {, grand mal, } \\
\text { onset age } 12\end{array}$ & $1 / 7$, single seizure & $1 / 3$ & $2 / 4$ & NR & $1 / 4$ & $\begin{array}{l}+ \text {, grand mal onset } \\
\text { age } 27\end{array}$ & $7 / 20$ \\
\hline $\begin{array}{l}\text { Recognizable } \\
\text { facial features }\end{array}$ & - & - & - & NR & NR & - & - & not present \\
\hline $\begin{array}{l}\text { Medical problems, } \\
\text { age of onset (when } \\
\text { documented) }\end{array}$ & - & $\begin{array}{l}\text { 1/7 severe myopia } \\
3 / 7 \text { kyphosis/ } \\
\text { scoliosis }\end{array}$ & NR & NR & NR & $\begin{array}{l}1 / 4 \text { congestive } \\
\text { heart failure, } \\
\text { onset age } 39 \\
1 / 4 \text { kyphoscoliosis }\end{array}$ & $\begin{array}{l}\text { bilateral cataract } \\
\text { age } 30 \text {, episodes of } \\
\text { unexplained diar- } \\
\text { rhea; death at age } 39 \\
\text { from pneumonia }\end{array}$ & $\begin{array}{l}\text { variable, } \\
4 / 24 \text { kyphosis/ } \\
\text { scoliosis }\end{array}$ \\
\hline $\begin{array}{l}\text { Adult growth param } \\
\text { head circumferenc }\end{array}$ & $\begin{array}{l}\text { eters } \\
\text { e P25-P50 }\end{array}$ & $3 / 7<\mathrm{P} 3$ & $1 / 3$ normal, $2 / 3 \mathrm{NR}$ & $2 / 4<\mathrm{P} 3$ & $4 / 4$ normal & $4 / 4$ normal & normal & $5 / 22<\mathrm{P} 3$ \\
\hline height & P16 & $6 / 7<\mathrm{P} 3$ & $2 / 3$ normal, $1 / 3 \mathrm{NR}$ & $4 / 4<\mathrm{P} 3$ & NR & $2 / 4$ short stature & NR & $12 / 18$ short stature \\
\hline weight & $\mathrm{P} 2$ & $>\mathrm{P} 98$ in $2 / 5$ & $\mathrm{NR}$ & $3 / 4$ obesity & NR & $1 / 4$ obesity & NR & 6/14 obesity \\
\hline Other & - & - & - & - & - & $\begin{array}{l}\text { macro-orchidism, } \\
\text { pyramidal signs }\end{array}$ & siallorhoe & $\begin{array}{l}\text { no consistent other } \\
\text { features }\end{array}$ \\
\hline Family history & $\begin{array}{l}\text { learning disabil- } \\
\text { ities in mother } \\
\text { and sister, } \\
\text { mother has se- } \\
\text { vere psychiatric } \\
\text { problems }\end{array}$ & $\begin{array}{l}\text { patients are from } \\
\text { the same family, } \\
\text { carrier females all } \\
\text { normal intelligent }\end{array}$ & $\begin{array}{l}4 \text { affected males in } \\
\text { one family, no } \\
\text { information about } \\
\text { carrier females }\end{array}$ & $\begin{array}{l}\text { progressive tremor } \\
\text { in } 2 \text { carrier females, } \\
\text { normal intelligence } \\
\text { in carrier females }\end{array}$ & $\begin{array}{l}\text { mother and } \\
\text { carrier sister } \\
\text { have mild ID }\end{array}$ & $\begin{array}{l}\text { mother low } \\
\text { intelligence }\end{array}$ & $\begin{array}{l}\text { borderline intelli- } \\
\text { gence in } 1 \text { of } 2 \\
\text { carrier females; } \\
\text { severe ID in nephew }\end{array}$ & $\begin{array}{l}\text { all familial cases; } \\
\text { in } 4 / 6 \text { families } \\
\text { carrier females have } \\
\text { mild ID/learning } \\
\text { difficulties } \\
\text { (NR in } 1 \text { family) }\end{array}$ \\
\hline
\end{tabular}

$\mathrm{MRX} / \mathrm{T} / \mathrm{X} / \mathrm{MR}$ numbers in the heading refer to the family identification numbers in the original papers.

$\mathrm{MBD}=$ Methyl-binding domain; $\mathrm{P}=$ percentile. 
Table 4. Clinical features in present and previously reported patients with CDKL5 mutations

\begin{tabular}{|c|c|c|c|c|c|c|c|c|}
\hline & Present patient & $\begin{array}{l}\text { Weaving } \\
\text { et al. [2004] }\end{array}$ & $\begin{array}{l}\text { Weaving } \\
\text { et al. [2004] }\end{array}$ & Tao et al. [2004] & $\begin{array}{l}\text { Archer } \\
\text { et al. [2006] }\end{array}$ & $\begin{array}{l}\text { Bahi-Buisson } \\
\text { et al. [2008a, b] }\end{array}$ & Erez et al. [2009] & Total \\
\hline Mutation & c. $464-1 \mathrm{G}>\mathrm{A}$ & c.183delT & IVS13-1G>A & $525 \mathrm{~A}>\mathrm{T}(\mathrm{R} 175 \mathrm{~S})$ & c.del2362_2366 & $\begin{array}{l}\text { C1892.1893dupTA/ } \\
\text { c.229delGAAG }\end{array}$ & Del exon 1a-3 & \\
\hline Number of adults & 1 & 2 & 1 & 2 & 1 & 2 & 1 & 10 \\
\hline Age, years & 47 & 19 (twins) & 28 & 41 (twins) & 18 & 19,26 & 20 & $18-47$ \\
\hline Sex & $\mathrm{f}$ & $\mathrm{f}$ & $\mathrm{f}$ & $\mathrm{f}$ & $\mathrm{f}$ & $\mathrm{f}$ & $\mathrm{f}$ & $10 \mathrm{f}$ \\
\hline $\begin{array}{l}\text { Developmental } \\
\text { outcome }\end{array}$ & $\begin{array}{l}\text { severe ID, } \\
\text { no speech }\end{array}$ & $\begin{array}{l}\text { severe ID, } \\
\text { no speech } \\
\text { in twin } 1 \text {, } \\
\text { mild ID in twin } 2\end{array}$ & $\begin{array}{l}\text { severe ID, } \\
\text { no speech }\end{array}$ & $\begin{array}{l}\text { severe ID in both, } \\
\text { no speech }\end{array}$ & $\begin{array}{l}\text { severe ID, } \\
\text { speech in phrases }\end{array}$ & $\begin{array}{l}\text { severe ID, first } \\
\text { patient able to } \\
\text { speak } 3 \text {-word } \\
\text { sentences, second } \\
\text { patient no speech }\end{array}$ & $\begin{array}{l}\text { severe ID, } \\
\text { no speech }\end{array}$ & $\begin{array}{l}9 / 10 \text { severe ID } \\
1 / 10 \text { mild ID } \\
\text { (speech is rare) }\end{array}$ \\
\hline Motor signs & $\begin{array}{l}\text { spastic tetra- } \\
\text { plegia, unable } \\
\text { to walk without } \\
\text { support, ataxia }\end{array}$ & $\begin{array}{l}\text { wheelchair bound, } \\
\text { generalized spasticity, } \\
\text { hyperreflexia (twin 1) }\end{array}$ & unsteady gait & $\begin{array}{l}\text { one is wheelchair } \\
\text { bound, twin sister } \\
\text { is able to walk since } \\
\text { age } 8 \text { with support; } \\
\text { in both mild ataxia }\end{array}$ & $\begin{array}{l}\text { motor dyspraxia, } \\
\text { limited hand skills, } \\
\text { hypotonia, but } \\
\text { walks and swims }\end{array}$ & $\begin{array}{l}\text { unable to walk, } \\
\text { limited hand skills }\end{array}$ & $\begin{array}{l}\text { wheelchair bound, } \\
\text { hyporeflexia }\end{array}$ & $\begin{array}{l}\text { 10/10, comprising } \\
\text { pyramidal and } \\
\text { sometimes } \\
\text { cerebellar } \\
\text { components }\end{array}$ \\
\hline $\begin{array}{l}\text { Regression } \\
\text { (of psycho- } \\
\text { motor function) }\end{array}$ & $\begin{array}{l}+ \text {, decline } \\
\text { motor func- } \\
\text { tioning }\end{array}$ & $\begin{array}{l}\text { twin } 1:+ \text { normal de- } \\
\text { velopment until } 10 \\
\text { months, then loss of } \\
\text { skills }\end{array}$ & $\begin{array}{l}+ \text {, between ages } \\
2 \text { and } 5 \text { years } \\
\text { loss of skills }\end{array}$ & not significant & - & - & $\begin{array}{l}+ \text {, between ages } \\
4 \text { and } 7 \text { years }\end{array}$ & $4 / 10$ \\
\hline $\begin{array}{l}\text { Behavior/ } \\
\text { psychiatric }\end{array}$ & $\begin{array}{l}\text { self-mutilation, } \\
\text { stereotypic } \\
\text { movements } \\
\text { (hand biting), } \\
\text { hyperactivity, } \\
\text { no sense of fear }\end{array}$ & $\begin{array}{l}\text { twin 1: poor eye } \\
\text { contact, hand } \\
\text { stereotypies }\end{array}$ & $\begin{array}{l}\text { hand stereotypies, } \\
\text { dystonia, sleep } \\
\text { disturbances }\end{array}$ & $\begin{array}{l}\text { hand stereotypies, } \\
\text { mood swings, little } \\
\text { eye contact and } \\
\text { interaction with } \\
\text { environment in both }\end{array}$ & $\begin{array}{l}\text { hand stereotypies, } \\
\text { autism, bruxism, } \\
\text { mood lability, } \\
\text { sleep disturbance }\end{array}$ & $\begin{array}{l}\text { hand stereotypies, } \\
\text { autistic features, } \\
\text { sleep disturbances } \\
\text { (both); bruxism (2) }\end{array}$ & NR & $\begin{array}{l}8 / 9 \text { hand } \\
\text { stereotypies } \\
6 / 9 \text { poor social } \\
\text { interaction/autism } \\
4 / 9 \text { sleep } \\
\text { disturbance }\end{array}$ \\
\hline \multicolumn{9}{|l|}{ Seizures } \\
\hline $\begin{array}{l}\text { type and severity, } \\
\text { therapy resistance }\end{array}$ & $\begin{array}{l}\text { atonic, intrac- } \\
\text { table; persistent } \\
\text { seizures despite } \\
\text { multiple } \\
\text { medications }\end{array}$ & $\begin{array}{l}\text { 1/2 infantile spasms, } \\
\text { later mixed }^{\mathrm{a}} \\
\text { seizure disorder } \\
\text { 1/2: no seizures }\end{array}$ & $\begin{array}{l}\text { severe infantile } \\
\text { spasms, later } \\
\text { mixed intractable } \\
\text { seizures }\end{array}$ & $\begin{array}{l}\text { infantile spasms } \\
\text { until } 6 \text { months in } \\
\text { both, later absences } \\
\text { (in one of the twins) }\end{array}$ & $\begin{array}{l}\text { West syndrome, } \\
\text { subsequent severe } \\
\text { mixed seizure } \\
\text { disorder }\end{array}$ & $\begin{array}{l}\text { no infantile spasms } \\
1 / 2 \text { refractory } \\
\text { seizures } \\
1 / 2 \text { seizure arrest } \\
\text { at } 2 \text { weeks }\end{array}$ & $\begin{array}{l}+, \text { mixed, intrac- } \\
\text { table and therapy } \\
\text { resistent }\end{array}$ & $\begin{array}{l}\text { 9/10 } \\
\text { 9/9 early onset } \\
8 / 9 \text { persistent se- } \\
\text { vere seizure disor- } \\
\text { der into adulthood }\end{array}$ \\
\hline Facial features & coarseness & NR & no dysmorphism & NR & NR & NR & $\begin{array}{l}\text { coarseness, bilat- } \\
\text { eral exotropia }\end{array}$ & $\begin{array}{l}2 / 3 \text { coarseness } \\
\text { (possibly due to } \\
\text { anti-epileptic } \\
\text { medication) }\end{array}$ \\
\hline Medical problems & $\begin{array}{l}\text { Pes equino- } \\
\text { varus (related } \\
\text { to spasticity), } \\
\text { gastrostomy } \\
\text { tube }\end{array}$ & $\begin{array}{l}\text { thoracolumbal } \\
\text { scoliosis }\end{array}$ & scoliosis & $\begin{array}{l}\text { progressive dorso- } \\
\text { lumbal scoliois in } \\
\text { and flexion contrac- } \\
\text { tures in both }\end{array}$ & - & NR & gastrostomy tube & $\begin{array}{l}6 / 8 \text { locomotor } \\
\text { tract problems } \\
\text { secondary to } \\
\text { spasticity } \\
2 \text { patients with } \\
\text { gastrostomy } \\
\text { because of feeding } \\
\text { difficulties }\end{array}$ \\
\hline \multicolumn{9}{|c|}{ Adult growth parameters } \\
\hline height & $<\mathrm{P} 16$ & $\begin{array}{l}1 / 2<\mathrm{P} 3 \\
1 / 2 \mathrm{P} 3-\mathrm{P} 10\end{array}$ & NR & $\mathrm{NR}$ & normal & NR & normal & 1/8 short stature \\
\hline weight & $\mathrm{P} 2$ & $\begin{array}{l}1 / 2<\mathrm{P} 3 \\
1 / 2 \mathrm{P} 10-\mathrm{P} 25\end{array}$ & NR & NR & NR & NR & normal & $2 / 6$ cachexia \\
\hline $\begin{array}{l}\text { Autonomic } \\
\text { features }\end{array}$ & constipation & $\begin{array}{l}1 / 2 \text { : breathing } \\
\text { abnormalities, } \\
\text { peripheral vasomotor } \\
\text { disturbance; severe } \\
\text { constipation }\end{array}$ & + & $\begin{array}{l}\text { episodes of } \\
\text { hyperventilation, } \\
\text { abdominal } \\
\text { distention in both }\end{array}$ & - & $1 / 2$ & NR & $5 / 9$ \\
\hline Other & $\begin{array}{l}\text { small hands, } \\
\text { corpus callosum } \\
\text { agenesis }\end{array}$ & $\begin{array}{l}\text { small hands and feet; } \\
\text { male brother also } \\
\text { affected, died at age } \\
16 \text { of respiratory } \\
\text { failure }\end{array}$ & $\begin{array}{l}\text { small feet, } \\
\text { hirsutism }\end{array}$ & NR & NR & NR & acne, hirsutism & $\begin{array}{l}4 / 7 \text { small hands } \\
\text { and/or feet }\end{array}$ \\
\hline
\end{tabular}

$\mathrm{P}=$ Percentile. ${ }^{\mathrm{a}}$ Mixed: tonic-clonic, myoclonic, absences. 
Table 5. Clinical features of present and previously reported patients with genetically confirmed Dravet syndrome

\begin{tabular}{|c|c|c|c|c|c|}
\hline & Present patient 5 & Present patient 6 & Jansen et al. [2006] & Akiyama et al. [2010] & Total \\
\hline Number of patients & 1 & 1 & 10 & 25 & 37 \\
\hline Mutation & c.5304T>G (p.Ser1768Arg) & c.3526delG (p.Glu1176fs) & NR & $\begin{array}{l}14 / 25 \text { missense } \\
5 / 25 \text { nonsense } \\
6 / 25 \text { frameshift }\end{array}$ & missense $>$ frameshift $>$ nonsense \\
\hline Age, years & 34 & 49 & mean 26 (range 18-47) & $18-43$ & $18-49$ \\
\hline Gender & $\mathrm{m}$ & $\mathrm{m}$ & NR & $9 \mathrm{~m}, 16 \mathrm{f}$ & $11 \mathrm{~m}, 16 \mathrm{f}, 10 \mathrm{NR}$ \\
\hline $\begin{array}{l}\text { Developmental } \\
\text { outcome }\end{array}$ & severe ID, no speech & $\begin{array}{l}\text { severe ID, very little } \\
\text { speech }\end{array}$ & $\begin{array}{l}1 / 10 \text { normal } \\
4 / 10 \text { moderate ID } \\
5 / 10 \text { severe ID }\end{array}$ & $\begin{array}{l}24 / 25 \text { severe ID } \\
6 / 25 \text { no speech } \\
8 / 25 \text { very limited speech } \\
6 / 25 \text { single words } \\
4 / 25 \text { simple speech } \\
\text { 1/25 mild ID }\end{array}$ & $\begin{array}{l}\text { 31/37 severe ID } \\
4 / 37 \text { moderate ID } \\
1 / 37 \text { mild ID } \\
1 / 37 \text { no ID }\end{array}$ \\
\hline Motor symptoms & $\begin{array}{l}\text { mild right-sided hemiplegia, } \\
\text { after epileptic state, able to walk }\end{array}$ & clumsiness, spasticity & $\begin{array}{l}\text { 5/10 pyramidal } \\
3 / 10 \text { cerebellar } \\
4 / 10 \text { extrapyramidal } \\
2 / 10 \text { no motor signs }\end{array}$ & $\begin{array}{l}2 / 25 \text { bedridden } \\
11 / 25 \text { clumsy } \\
7 / 25 \text { ataxia } \\
5 / 25 \text { no motor signs }\end{array}$ & $\begin{array}{l}30 / 37 \text { motor signs, comprising } \\
\text { pyramidal, cerebellar and } \\
\text { extrapyramidal signs }\end{array}$ \\
\hline Regression & + , onset at age 2 years & - & uncommon & $5 / 25$ & $6 / 27$ \\
\hline $\begin{array}{l}\text { Behavior/ } \\
\text { psychiatric }\end{array}$ & $\begin{array}{l}\text { very friendly, little initiative, } \\
\text { obsessive traits, self-mutilation, } \\
\text { very high threshold of pain }\end{array}$ & $\begin{array}{l}\text { friendly personality, } \\
\text { loves to get attention }\end{array}$ & NR & NR & $\begin{array}{l}2 / 2 \text { cooperative and friendly } \\
\text { personality }\end{array}$ \\
\hline \multicolumn{6}{|l|}{ Seizures } \\
\hline age at onset & 5 months & 6 months & $3-8$ months & $<$ first year of life & $37 / 37$ onset within first year of life \\
\hline seizure types & absences, tonic-clonic & mixed & $\begin{array}{l}\text { at onset: } 1 / 10 \text { myclonic, } \\
4 / 10 \text { generalized tonic-clonic, } \\
5 / 10 \text { febrile; } \\
\text { later: mixed seizures in } 8 / 10 \\
\text { (tonic-clonic, absences, } \\
\text { mycoclonic, partial) }\end{array}$ & $\begin{array}{l}\text { generalized at adult age, } \\
\text { only in } 6 \text { mixed seizures }\end{array}$ & variable types of seizures \\
\hline severity & $\begin{array}{l}\text { once epileptic state, intractable } \\
\text { seizures despite multiple } \\
\text { anti-epileptic drugs }\end{array}$ & $\begin{array}{l}\text { intractable seizures } \\
\text { despite multiple } \\
\text { anti-epileptic drugs }\end{array}$ & intractable seizures in $10 / 10$ & $\begin{array}{l}\text { intractable in } 20 / 25 \text {; } \\
\text { in } 5 \text { seizures suppressed } \\
\text { for } 1-3 \text { years }\end{array}$ & $\begin{array}{l}32 / 37 \text { intractable seizures } \\
\text { persisting throughout adulthood }\end{array}$ \\
\hline $\begin{array}{l}\text { Recognizable facial } \\
\text { features }\end{array}$ & - & - & NR & NR & not present \\
\hline Medical problems & $\begin{array}{l}\text { upper and lower airway } \\
\text { infections }\end{array}$ & $\begin{array}{l}\text { high hypermetropia and } \\
\text { a substantial astigmatism }\end{array}$ & NR & $\begin{array}{l}1 \text { patient described as } \\
\text { case report: pneumonia }\end{array}$ & $\begin{array}{l}2 / 3 \text { airway infection (not } \\
\text { systematically reported) }\end{array}$ \\
\hline Growth parameters & normal & normal & NR & NR & $12 / 12$ normal \\
\hline
\end{tabular}

present 2 patients, is summarized in table 5. Age ranged from 18-49 years. The majority of patients had a poor developmental outcome with severe ID in more than $80 \%$. Seventy-five percent had motor symptoms (including pyramidal, cerebellar, and extrapyramidal symptoms), varying from clumsiness to being bedridden. Regression was uncommon. In $86 \%$ of all patients, intractable seizures with a history of early onset in the first year of life persisted into adulthood. Behavior characteristics were not systematically reported, though the present 2 patients both had a friendly and cooperative personality. Medical problems were not systematically reported. Poor developmental and seizure outcome in combination with motor symptoms but lack of other specific features might be indicative of Dravet syndrome in adult male and female patients.

Phelan-McDermid Syndrome. Clinical features of the present patients and 15 previously reported adult patients are summarized in table 6 . The age of the patients ranged from 19-49 years, and the present patient 7 was the oldest one reported. Developmental outcome varied from mild to severe ID. Most patients did have some speech ability. We observed a tendency to deterioration in motor functioning above the age of 40 years, including presence of pyramidal signs. The present patient 7 showed a severe decline in motor functioning as well as in cognitive and health performance. About half of the patients did at least have one seizure during lifetime, but severe seizure dis- 


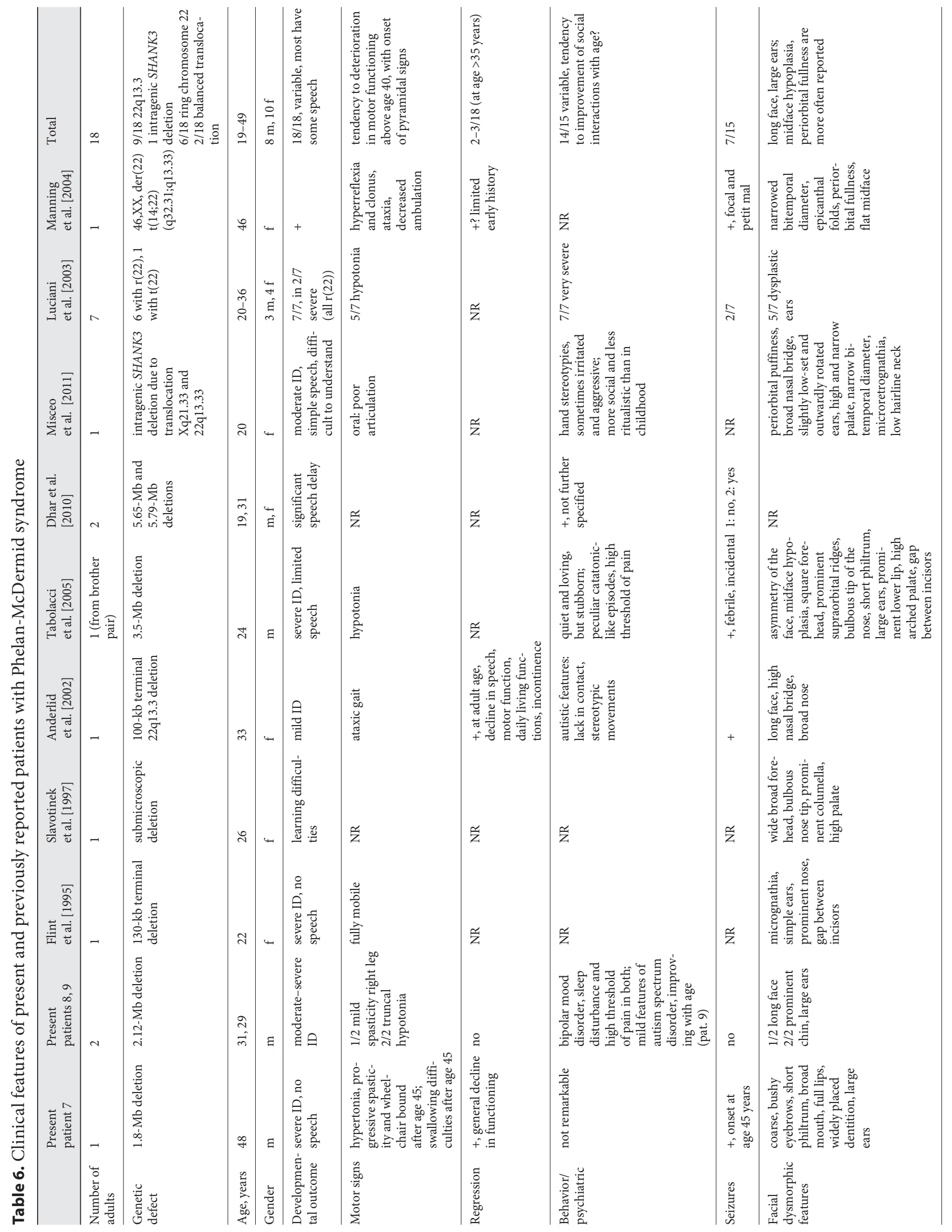




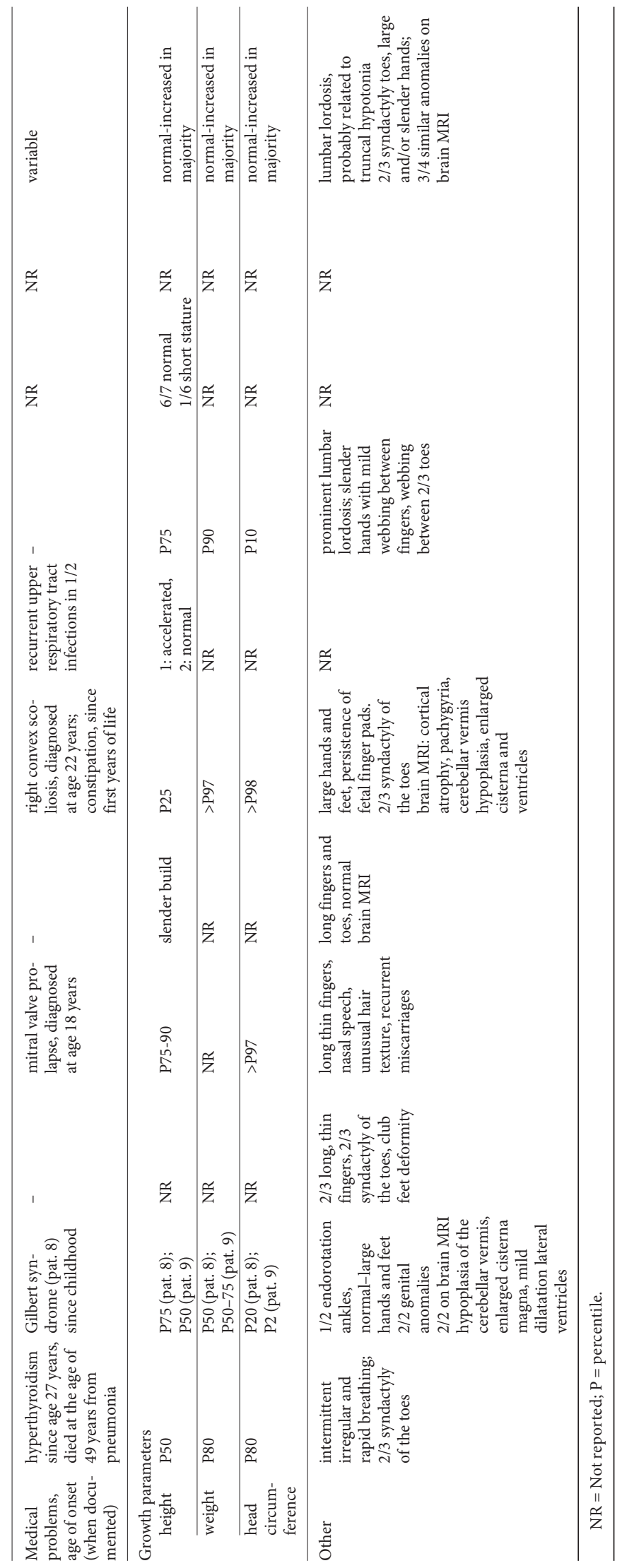

Adult Phenotypes in Angelman- and Rett-Like Syndromes orders were not reported. The majority of the adult patients had variable behavior problems, including autistic behavioral features, though in some patients these seemed to improve with age. Other features that were more frequently reported included a long face and large ears, large and/or slender hands/feet, and hypotonia with/without lumbar lordosis. In 4 patients, including the present patients 8 and 9, results of cerebral imaging by MRI were reported. Interestingly, in 3 of these patients similar anomalies, comprising cerebellar vermis hypoplasia, enlargement of the cisterna magna, and dilatation of ventricles, were observed.

\section{Discussion}

The adult phenotype of most of the presented syndromes has not been systematically reviewed and described in previous reports, except for SCN1A mutations involved in Dravet syndrome [Jansen et al., 2006; Akiyama et al., 2010].

We described the phenotype of 9 adults with 6 different Angelman- and Rett-like syndromes and reviewed previously reported adult cases in the literature. As in childhood patients, adult patients with the reported Angelman- and Rett-like syndromes showed an overlapping phenotypic spectrum as well. Despite the relatively low numbers of patients in each group that have been reported so far, a tendency to specific phenotypic differences at adult age with respect to evolution of the phenotype and outcome could be observed, though conclusions are hampered by the small numbers (table 7). Patients with Kleefstra syndrome, males with MECP2 mutations, and females with CDKL5 mutations showed a further decline in functioning/regression at adult age, whereas patients with Pitt Hopkins syndrome and Dravet syndrome seemed to have a relatively stable performance. The prognosis with regard to the outcome of epilepsy showed also significant differences, with the poorest outcome in Dravet syndrome patients and patients with CDKL5 mutations. Motor symptoms were clearly present in some syndromes, including male Rett syndrome, Kleefstra syndrome (catatonic phenomena), and in patients with CDKL5 mutations, but absent or minor in other syndromes. Distinctive behavior patterns could be observed as well, for example adult onset of periods with passivity, decreased responsiveness and hypoactivity in Kleefstra syndrome, and Rett syndrome like behaviors in patients with CDKL5 mutations. Major medical problems, except for severe epilepsy, were in- 
Table 7. Distinguishing features in adult patients with different Angelman- and Rett-like syndromes

\begin{tabular}{|c|c|c|c|c|c|c|}
\hline & Kleefstra syndrome & Pitt Hopkins syndrome & $\begin{array}{l}M E C P 2 \text { mutations in } \\
\text { males }\end{array}$ & CDKL5 mutations & Dravet syndrome & $\begin{array}{l}\text { Phelan-McDermid } \\
\text { syndrome }\end{array}$ \\
\hline Facial appearance & recognizable & recognizable & non-recognizable & non-recognizable & non-recognizable & $\begin{array}{l}\text { subtle, including } \\
\text { long face, large ears }\end{array}$ \\
\hline Epilepsy & $+/-$, mild & $+/-$, mild & $+/-$, mild & + , intractable & + , intractable & $+/-$, mild \\
\hline Motor symptoms & $+/-$, catatonic phenomena & +/- mild & $\begin{array}{l}+, \text { pyramidal, tremors, } \\
\text { cerebellar }\end{array}$ &,+ pyramidal, cerebellar & $\begin{array}{l}+ \text {, pyramidal, } \\
\text { cerebellar }\end{array}$ & - \\
\hline Degree of ID & moderate-severe & severe & mild-profound & mostly severe & severe & mild-severe \\
\hline Regression & $+(6 / 11)$, at adult age & - & $+(1 / 3)$ at adult age & $+(4 / 10)$ & - & $+1-$ \\
\hline $\begin{array}{l}\text { Typical behavior/ } \\
\text { psychiatric features }\end{array}$ & $\begin{array}{l}\text { adult age onset periods with } \\
\text { passivity, decreased respon- } \\
\text { siveness and hypoactivity; } \\
\text { sleep disturbance }\end{array}$ & $\begin{array}{l}\text { mostly happy disposition, } \\
\text { but diverse behavior } \\
\text { problems including pica } \\
\text { and self-mutilation }\end{array}$ & $\begin{array}{l}\text { mood/depression and } \\
\text { anxiety disorders; } \\
\text { shyness and passivity }\end{array}$ & $\begin{array}{l}\text { (hand) stereotypies and poor } \\
\text { social interaction }\end{array}$ & $\begin{array}{l}\text { friendly and } \\
\text { cooperative in } \\
\text { general }\end{array}$ & $\begin{array}{l}\text { autistic features, } \\
\text { mood disorders }\end{array}$ \\
\hline $\begin{array}{l}\text { Signs of autonomic } \\
\text { dysfunction }\end{array}$ & - & $\begin{array}{l}\text { abnormal breathing } \\
\text { pattern, constipation }\end{array}$ & - & $\begin{array}{l}\text { breathing anomalies, cold and } \\
\text { purple feet/vasomotor disturbance, } \\
\text { severe constipation }\end{array}$ & - & $\begin{array}{l}+/- \text { abnormal } \\
\text { breathing pattern } \\
\text { in present patient } 7\end{array}$ \\
\hline Growth parameters & $\begin{array}{l}\text { microcephaly, short stature, } \\
\text { and obesity in about } 50 \% \text {; } \\
\text { obesity }\end{array}$ & $\begin{array}{l}\text { microcephaly and short } \\
\text { stature in majority }\end{array}$ & $\begin{array}{l}\text { microcephaly and } \\
\text { short stature in } \\
\text { majority }\end{array}$ & normal-decreased & normal & normal-increased \\
\hline $\begin{array}{l}\text { Medical problems } \\
\text { and/or other } \\
\text { distinctive features }\end{array}$ & $\begin{array}{l}\text { no consistently occurring } \\
\text { medical problems }\end{array}$ & $\begin{array}{l}\text { typical clubbing of } \\
\text { finger- and toenails }\end{array}$ & $\begin{array}{l}\text { spinal column } \\
\text { deformity }\end{array}$ & $\begin{array}{l}\text { spinal column deformity, scolio- } \\
\text { sis; small hands and/or feet; } \\
\text { feeding problems/gastrostomy }\end{array}$ & $\begin{array}{l}\text { airway infections } \\
\text { more often reported }\end{array}$ & $\begin{array}{l}\text { long and/or slender } \\
\text { fingers/toes, } \\
2 / 3 \text { syndactyly toes }\end{array}$ \\
\hline $\begin{array}{l}\text { Life expectancy } \\
\text { (oldest reported } \\
\text { patient, years) }\end{array}$ & 59 & 40 & 56 & 47 & 49 & 49 (died at this age) \\
\hline
\end{tabular}

frequently reported in adult patients with the presented Angelman- and Rett-like syndromes. Observed medical problems were mostly secondary to motor complications, for example secondary scoliosis, contractures, feeding difficulties, and airway infections due to spasticity, which were predominantly observed in patients with mutations in CDKL5, MECP2, and SCN1A.

Patients with Kleefstra syndrome and Pitt Hopkins syndrome retain the recognizable facial features at adult age, and thus, in these patients their facial appearance is an important clue to the diagnosis.

In conclusion, the combination of different key clinical features at adult age might be helpful to distinguish specific Angelman- and Rett-like syndromes from each other. These key features comprise the degree of ID, seizure characteristics, motor symptoms, occurrence of regression and characteristic facial appearance (Pitt Hopkins syndrome and Kleefstra syndrome). Knowledge about and insight in syndrome specific adult clinical characteristics facilitates adequate management and follow-up of patients with Angelman- and Rett-like syndromes and enables careful counseling of family members regarding prognosis, natural course of the disease, and life expectancy.

\section{Acknowledgements}

We thank the participating patients and their families and the participating specialist physicians for people with intellectual disability. In addition, we thank Prof. W.M.A. Verhoeven associated with the Vincent van Gogh Institute for Psychiatry, Centre of Excellence for Neuropsychiatry, Venray, The Netherlands and the Erasmus University Medical Centre, Department of Psychiatry, Rotterdam, the Netherlands for his valuable contribution to the discussion on the adult phenotypes. This work was supported by grants from the Consortium 'Stronger on your own feet' (to T.K., J.H.M.R., H.M.J.S.-L.V. and M.H.W), GENCODYS, an EU FP7 large-scale integrating project grant (Grant agreement no. 241995), and The Netherlands Organization for Health Research and Development (ZonMw Fellowship grant no. 907-00-365 to T.K.).

References

Willemsen et al.
Akiyama M, Kobayashi K, Yoshinaga H, Ohtsuka Y: A long-term follow-up study of Dravet syndrome up to adulthood. Epilepsia 51: 1043-1052 (2010).

- Amir RE, Van den Veyver IB, Wan M, Tran CQ, Francke U, et al: Rett syndrome is caused by mutations in X-linked $M E C P 2$, encoding methyl-CpG-binding protein 2. Nat Genet 23:185-188 (1999). 
-Anderlid BM, Schoumans J, Annerén G, TapiaPaez I, Dumanski J, et al: FISH-mapping of a $100-\mathrm{kb}$ terminal 22q13 deletion. Hum Genet 110:439-443 (2002).

-Archer HL, Evans J, Edwards S, Colley J, Newbury-Ecob R, et al: CDKL5 mutations cause infantile spasms, early onset seizures, and severe mental retardation in female patients. J Med Genet 43:729-734 (2006).

-Ariani F, Hayek G, Rondinella D, Artuso R, Mencarelli MA, et al: FOXG1 is responsible for the congenital variant of Rett syndrome. Am J Hum Genet 83:89-93 (2008).

-Bahi-Buisson N, Kaminska A, Boddaert N, Rio M, Afenjar A, et al: The three stages of epilepsy in patients with CDKL5 mutations. Epilepsia 49:1027-1037 (2008a).

-Bahi-Buisson N, Nectoux J, Rosas-Vargas H, Milh M, Boddaert N, et al: Key clinical features to identify girls with CDKL5 mutations. Brain 131:2647-2661 (2008b).

-Claes S, Devriendt K, D’Adamo P, Meireleire J, Raeymaekers $\mathrm{P}$, et al: X-linked severe mental retardation and a progressive neurological disorder in a Belgian family: clinical and genetic studies. Clin Genet 52:155-161 (1997).

-Claes L, Del-Favero J, Ceulemans B, Lagae L, Van Broeckhoven C, et al: De novo mutations in the sodium-channel gene SCN1A cause severe myoclonic epilepsy of infancy. Am J Hum Genet 68:1327-1332 (2001).

-Couvert P, Bienvenu T, Aquaviva C, Poirier K, Moraine $\mathrm{C}$, et al: $M E C P 2$ is highly mutated in X-linked mental retardation. Hum Mol Genet 10:941-946 (2001).

- Dhar SU, del Gaudio D, German JR, Peters SU, Ou Z, et al: 22q13.3 deletion syndrome: clinical and molecular analysis using array CGH. Am J Med Genet A 152A:573-581 (2010).

-Erez A, Patel AJ, Wang X, Xia Z, Bhatt SS, et al: Alu-specific microhomology-mediated deletions in CDKL5 in females with early-onset seizure disorder. Neurogenetics 10:363-369 (2009).

-Flint J, Wilkie AO, Buckle VJ, Winter RM, Holland $\mathrm{AJ}$, et al: The detection of subtelomeric chromosomal rearrangements in idiopathic mental retardation. Nat Genet 9:132-140 (1995).

- Gendrot C, Ronce N, Raynaud M, Ayrault AD, Dourlens J, et al: X-linked nonspecific mental retardation (MRX16) mapping to distal Xq28: linkage study and neuropsychological data in a large family. Am J Med Genet 83: 411-418 (1999).

- Gomot M, Gendrot C, Verloes A, Raynaud M, David $\mathrm{A}$, et al: $M E C P 2$ gene mutations in non-syndromic X-linked mental retardation: phenotype-genotype correlation. Am J Med Genet A 123A:129-139 (2003).

-Jansen FE, Sadleir LG, Harkin LA, Vadlamudi L, McMahon JM, et al: Severe myoclonic epilepsy of infancy (Dravet syndrome): recognition and diagnosis in adults. Neurology 67: 2224-2226 (2006).
Kalscheuer VM, Tao J, Donnelly A, Hollway G, Schwinger E, et al: Disruption of the serine/ threonine kinase 9 gene causes severe $\mathrm{X}$ linked infantile spasms and mental retardation. Am J Hum Genet 72:1401-1411 (2003).

Klauck SM, Lindsay S, Beyer KS, Splitt M, Burn $\mathrm{J}$, et al: A mutation hot spot for nonspecific $\mathrm{X}$-linked mental retardation in the MECP2 gene causes the PPM-X syndrome. Am J Hum Genet 70:1034-1037 (2002).

Kleefstra T, Yntema HG, Oudakker AR, Romein T, Sistermans E, et al: De novo MECP2 frameshift mutation in a boy with moderate mental retardation, obesity and gynaecomastia. Clin Genet 61:359-362 (2002).

-Kleefstra T, Yntema HG, Nillesen WM, Oudakker AR, Mullaart RA, et al: MECP2 analysis in mentally retarded patients: implications for routine DNA diagnostics. Eur J Hum Genet 12:24-28 (2004).

-Kleefstra T, Brunner HG, Amiel J, Oudakker AR, Nillesen WM, et al: Loss-of-function mutations in euchromatin histone methyl transferase 1 (EHMT1) cause the 9q34 subtelomeric deletion syndrome. Am J Hum Genet 79:370-377 (2006).

Kleefstra T, van Zelst-Stams WA, Nillesen WM, Cormier-Daire V, Houge G, et al: Further clinical and molecular delineation of the $9 \mathrm{q}$ subtelomeric deletion syndrome supports a major contribution of EHMT1 haploinsufficiency to the core phenotype. J Med Genet 46:598-606 (2009).

Lindsay S, Splitt M, Edney S, Berney TP, Knight SJ, et al: PPM-X: a new X-linked mental retardation syndrome with psychosis, pyramidal signs, and macroorchidism maps to Xq28. Am J Hum Genet 58:1120-1126 (1996).

Luciani JJ, de Mas P, Depetris D, Mignon-Ravix C, Bottani A, et al: Telomeric 22q13 deletions resulting from rings, simple deletions, and translocations: cytogenetic, molecular, and clinical analyses of 32 new observations. J Med Genet 40:690-696 (2003).

Makedonski K, Abuhatzira L, Kaufman Y, Razin A, Shemer R: MeCP2 deficiency in Rett syndrome causes epigenetic aberrations at the PWS/AS imprinting center that affects UBE3A expression. Hum Molec Genet 14: 1049-1058 (2005)

-Manning MA, Cassidy SB, Clericuzio C, Cherry AM, Schwartz S, et al: Terminal 22q deletion syndrome: a newly recognized cause of speech and language disability in the autism spectrum. Pediatrics 114:451-457 (2004).

Mari F, Azimonti S, Bertani I, Bolognese F, Colombo E, et al: CDKL5 belongs to the same molecular pathway of $\mathrm{MeCP} 2$ and it is responsible for the early-onset seizure variant of Rett syndrome. Hum Mol Genet 14:19351946 (2005).

Meloni I, Bruttini M, Longo I, Mari F, Rizzolio $\mathrm{F}$, et al: A mutation in the Rett syndrome gene, $M E C P 2$, causes X-linked mental retardation and progressive spasticity in males. Am J Hum Genet 67:982-985 (2000).
Misceo D, Rødningen OK, Barøy T, Sorte H, Mellembakken JR, et al: A translocation between Xq21.33 and 22q13.33 causes an intragenic SHANK3 deletion in a woman with Phelan-McDermid syndrome and hypergonadotropic hypogonadism. Am J Med Genet A 155:403-408 (2011).

-Moncla A, Kpebe A, Missirian C, Mancini J, Villard L: Polymorphisms in the C-terminal domain of MECP2 in mentally handicapped boys: implications for genetic counselling. Eur J Hum Genet 10:86-89 (2002).

Moog U, Smeets EE, van Roozendaal KE, Schoenmakers S, Herbergs J, et al: Neurodevelopmental disorders in males related to the gene causing Rett syndrome in females (MECP2). Eur J Paediatr Neurol 7:5-12 (2003).

Moog U, Van Roozendaal K, Smeets E, Tserpelis $\mathrm{D}$, Devriendt K, et al: $M E C P 2$ mutations are an infrequent cause of mental retardation associated with neurological problems in male patients. Brain Dev 28:305-310 (2006).

Orrico A, Lam C, Galli L, Dotti MT, Hayek G, et al: MECP2 mutation in male patients with non-specific X-linked mental retardation. FEBS Lett 481:285-288 (2000).

- Papa FT, Mencarelli MA, Caselli R, Katzaki E, Sampieri K, et al: A $3 \mathrm{Mb}$ deletion in 14q12 causes severe mental retardation, mild facial dysmorphisms and Rett-like features. Am J Med Genet A 146A:1994-1998 (2008).

- Phelan MC, Rogers RC, Saul RA, Stapleton GA, Sweet K, et al: 22q13 deletion syndrome. Am J Med Genet 101:91-99 (2001).

- Rosenfeld JA, Leppig K, Ballif BC, Thiese H, Erdie-Lalena C, et al: Genotype-phenotype analysis of TCF4 mutations causing PittHopkins syndrome shows increased seizure activity with missense mutations. Genet Med 11:797-805 (2009).

Russo S, Marchi M, Cogliati F, Bonati MT, Pintaudi $M$, et al: Novel mutations in the CDKL5 gene, predicted effects and associated phenotypes. Neurogenetics 10:241250 (2009)

-Samaco RC, Hogart A, LaSalle JM: Epigenetic overlap in autism-spectrum neurodevelopmental disorders: $M E C P 2$ deficiency causes reduced expression of $U B E 3 A$ and GABRB3. Hum Molec Genet 14:483-492 (2005).

Schüle B, Armstrong DD, Vogel H, Oviedo A, Francke U: Severe congenital encephalopathy caused by $M E C P 2$ null mutations in males: central hypoxia and reduced neuronal dendritic structure. Clin Genet 74:116126 (2008).

-Slavotinek A, Maher E, Gregory P, Rowlandson $\mathrm{P}$, Huson SM. The phenotypic effects of chromosome rearrangement involving bands 7q21.3 and 22q13.3. J Med Genet 34:857-861 (1997).

Tabolacci E, Zollino M, Lecce R, Sangiorgi E, Gurrieri F, et al: Two brothers with 22q13 deletion syndrome and features suggestive of the Clark-Baraitser syndrome. Clin Dysmorphol 143:127-132 (2005). 
Takano K, Lyons M, Moyes C, Jones J, Schwartz CE: Two percent of patients suspected of having Angelman syndrome have TCF4 mutations. Clin Genet 78:282-288 (2010).

-Tao J, Van Esch H, Hagedorn-Greiwe M, Hoffmann K, Moser B, et al: Mutations in the Xlinked cyclin-dependent kinase-like 5 (CDKL5/STK9) gene are associated with severe neurodevelopmental retardation. Am J Hum Genet 75:1149-1154 (2004).

-Verhoeven WM, Kleefstra T, Egger JI: Behavioral phenotype in the $9 \mathrm{q}$ subtelomeric deletion syndrome: a report about two adult patients. Am J Med Genet B Neuropsychiatr Genet 153B:536-541 (2010).

-Verhoeven WM, Egger JI, Vermeulen K, van de Warrenburg BP, Kleefstra T: Kleefstra syndrome in three adult patients: further delineation of the behavioral and neurological phenotype shows aspects of a neurodegenerative course. Am J Med Genet A 155A:2409-2415 (2011).
Villard L: MECP2 mutations in males. J Med Genet 44:417-423 (2007).

-Watson P, Black G, Ramsden S, Barrow M, Super $M$, et al: Angelman syndrome phenotype associated with mutations in $M E C P 2$, a gene encoding a methyl CpG binding protein. J Med Genet 38:224-228 (2001).

-Weaving LS, Christodoulou J, Williamson SL, Friend KL, McKenzie OL, et al: Mutations of CDKL5 cause a severe neurodevelopmental disorder with infantile spasms and mental retardation. Am J Hum Genet 75:1079-1093 (2004).

Wilson HL, Wong AC, Shaw SR, Tse WY, Stapleton GA, et al: Molecular characterisation of the 22q13 deletion syndrome supports the role of haploinsufficiency of SHANK3/ PROSAP2 in the major neurological symptoms. J Med Genet 40:575-584 (2003). ntema HG, Oudakker AR, Kleefstra T, Hamel $B C$, van Bokhoven $\mathrm{H}$, et al: In-frame deletion in MECP2 causes mild nonspecific mental retardation. Am J Med Genet 107:81-83 (2002).

Zweier C, Peippo MM, Hoyer J, Sousa S, Bottani A, et al: Haploinsufficiency of TCF4 causes syndromal mental retardation with intermittent hyperventilation (Pitt-Hopkins syndrome). Am J Hum Genet 80:994-1001 (2007).

Zweier C, Sticht H, Bijlsma EK, Clayton-Smith J, Boonen SE, et al: Further delineation of PittHopkins syndrome: phenotypic and genotypic description of 16 novel patients. J Med Genet 45:738-744 (2008).

Zweier M, Gregor A, Zweier C, Engels H, Sticht $\mathrm{H}$, et al: Mutations in $M E F 2 C$ from the $5 \mathrm{q} 14.3 \mathrm{q} 15$ microdeletion syndrome region are a frequent cause of severe mental retardation and diminish MECP2 and CDKL5 expression. Hum Mutat 31:722-733 (2010). 